\title{
ÉRTEKEZÉSEK
}

A TERMÉSZETTUDOMÁNYOK KÖRÉBÖL.

KIADJA A MAGYAR TUD. AKADÉMIA.

A III. OSZTÁLY RENDELETÉBÖL

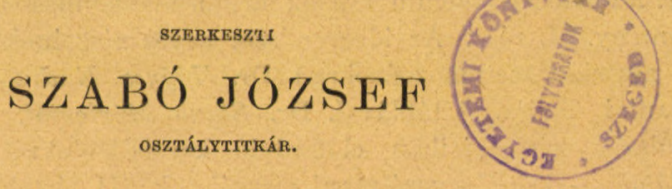

XIX. KÖTET. 6. SZÁM. 1889.

\section{A GERINCZVELŐI IDEGEK}

\section{HÁTULSÓ GYÖKEREIRŐL.}

Dr. LENHOSSÉK MIHÁLY

EGYETEMI MAGÁNTANÁRTóL.

(6 ábrával.)

(Mint vendég felolvasta a III. osztály ülésén 1889. május 20.)

Ára $40 \mathrm{kr}$.

BUDAPEST.

1889. 


\title{
ÉRTEKEZÉSEK
}

\section{A TERMÉSZETTUDOMÁNYOK KÖRÉBÖL.}

\author{
Első kötet. 1867-1870. - Második kötet. 1870-1871. - Harmadik \\ kötet. 1872. - Negyedik kötet. 1873. - Ötödik kötet. 1874. - Hato- \\ dik kötet. 1875. - Hetedik kötet. 1876. - Nyolozadik kötet. 1877. - \\ Kilenozedik kötet. 1878-1879. - Tizedik kötet. 1880.
}

\section{Tizenegyedik kötet. 1881.}

I. Az associált szemmozgások idegmechanismusáról. 2 fametszettel. (Második közlemény. II. rész. Az idegrend̦szer egyes részeinek befolyásáról az önkénytelen associált szemmozgásokra.) Dr. Högyes Endrétől. - II. A Frusca-gora aquitaniai flórája. 4 táblával. Dr. Staub Móricztól. - III. A pinguicula és utricularia sejtmagjaiban elöforduló krystalloidokról. (Egy táblával.) Klein Gyulitól. - IV. Vegyerélytani vizsgálatok. (II. értekezés.) Dr. Than Kärolytól. Egy tábla kőrajzzal. - V. Ujabb tanulmányok a kámforesoport körébỏl. Ballo Mátyástól. - VI. A homorodi vasas savanyuviz-források chemiai elemzése. Dr. Solymosi Lajostól. - VII. A solymosi hideg savanyu ásványviz chemiai elemzése. Dr. Hankó Vilmostól. - VIII. Önmïködö higanylégszivattyu. Schuller Alajostól. Egy rajzzal. - IX. Adatok a Mecsekhegység és dombvidéke jurakorbeli lerakodásainak ismeretéhez. (II. Palaeontologiai rész.) Böckh Jánostól. 10 tábla rajzzal. - X. A carludovica és a canna gummijáratairól. S zabó Ferencztöl. Egy táblával. - XI. Budapest fővárus ivóvizei egészségi - Aınpontból s nélıány ásványviz elemzése. Balló Mãtyãstól. - XII. EmlékDesavi William Stephen Atkinson külsö tag felett. Dr. Duka Tivadartól. XIII. Adatok a harántesiku izmok szerkezete- és idegvégződéséhez. (Székfoglaló értekezés.) - Thanhoffer Lajostól. Egy 4-es rétü tábla rajzzal. - XIV. A mohai (fehérmegyei) Agnes-forrás vegyelemzése. Dr. Lengyel Bélätól. - XV. Egy ujabb szerkeszetï, vizszivatyuval combinált higany-légszivatyuról. Dr. Lengyel Bélaitól. Egy tábla rajzzal. - XVI. Az elzöldült szarkaláb mint morphologiai utmutató. Borbás Vinczétöl. Egy tábla rajzzal. - XVII. A viznek képzödési melegéröl. Schuller Alajostól. - XVIII. Békésvármegye flórája. Dr. Borbàs Vinczétöl. - XIX. Rendhagyó köggombák. Hazslinszky Frigyestöl. Rajzokkal. - XX. Dolgozatok a k. m. tud. egyetem élettani intézetéből. Közli Jendrässik Jenö. (I. Adatok a szürödés tanához. Regéczy Nagy Imre tr. tanársegédtöl. II. A gyomor hámsejtjeiröl. Ballagi János tr. élettani gyakornoktól. III. A zsirfelszivódáshoz a gyomorban. Mátrai Gábor orvostanhallgatótól. IV. A zsirok átszivárgásáról, nevezetesen az epe befolyása alatt. Hutyra Ferencz orvostanhallgatótól. (Rajzokkal.) - XXI. Emlékbeszéd Kenessey Albert felett. Galgóczy Karolytól - XXII. A tudományok haladásának befolyása a selmeczvidéki bányamivelésre. Péch Antaltól. - XXIII. Vegyerélytani vizsgálatok. A calorimetrikus mérések adatainak összehasonlitásáról. Than Kärolytól. - XXVI. Közlemények a m. kir. egyetem vegytani laboratoriumából. Bemutatta Than Karoly. (I. A borkösav száraz lepárlási terményeiröl. Lieber. mann Leótól. II. Adatok a Carbonylsulfid physikai sajátságaihoz s tiszta Carbonylsulfid elöállitása. 2-ik közlemény. Ilosvay Lajostól.) - XXV. Közlemények az állatorvosi tanintézet vegytani laboratoriumából. Liebermann Leótól. (I. A kénessav kimutatása a borban és más folyadékban II. Egy készülék könnyen olvadó fémek és öntvények olvadási pontjának meghatározására.) Egy rajzzal. - XXVI. A hydrogen hyporoxyd képződése égés közben. II. Válasz a viz képződési melegének ügyében. Schuller Alajostól. 


\title{
55388
}

\section{ÉRTEKEZÉSEK}

\section{A TERMÉSZETTUDOMÁNYOK KÖRÉBÖL.}

KIADJA A MAGYAR TUD. AKADÉMTA.

A III. OSZTÁLY RENDELETÉBöL

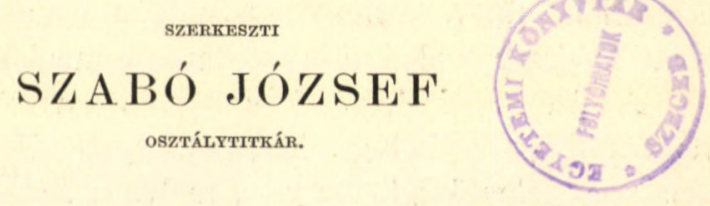

\section{A GERINCZVELÖI DEEGEK HÁTULSÓ GYÖKEREIRÖL.}

\author{
Dr. Lenhossék Minály \\ egyetemi magántanártós.
}

(6 ábrával.)

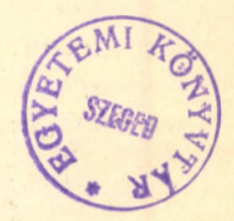

(Mint vendég felolvasta a III. osztály ülésén 1889. május 20.)

A hátulsó gyökereknek jelentékeny részök van a gerinczvelö megépítésében; a hátulsó nyalábokat csaknem egyedül a folytatásaik gyanánt ismerte fel a kutatás s kétségtelen vonatkozásuk van az oldalsó nyalábokhoz is. Már eleve világos, hogy ha rostjaik járását, kapcsolataikat pontosan ismerjük, a gerinczvelర̋ belső alkotásának ismeretéhez is nagy lépéssel közeledtünk.

A milyen fontos azonban, hogy az anatomia e szakasza végkép elkészüljön, ép oly nehézségekre akad itt útjában a kutatás. A hátulsó gyökerek, alig hogy a gerinczvelöbe léptek, szétoszlanak, elszóródnak egy-egy nagyobb területre, jó részök a hoszszanti nyalábokhoz szegödik; ha még hozzáveszszük, hogy rostjaik egy része a legfínomabbak közé 'tartozik, másrészt, hogy velösödésök olyan idöben fejeződik be, a mikor már sok egyéb velös a gerinczvelöben, úgy reámutattunk e nehézségek okaira.

Mint a tudomány minden oly fejezetében, a hol a vizsgálódás szövevényes tárgy elött áll: itt is igen eltérö nézetek merúl- 
tek fel az évek folyamán. E rostok járásának, végződésének csaknem valamennyi lehetösége ki van már merítve. Elmondhatjuk Terentiussal (Eunuchus, Prologus) : nullum est jam dictum, quod non dictum sit prius.

Ama számos dolgozat közül, a melyek e tárgygyal foglalkoznak, a legujabbak érdemlik meg leginkább figyelmünket. Nem mintha szerzöik megfigyelö tehetségét, megbízhatóságát többre becsülnők, mint a régibb szerzőkéit, hanem az alkalmazott vizsgálati módszer szolgáltatja az alapot e megkülönböztetésre.

A középponti idegrendszer kutatása az utóbbi években nevezetes módszerekkel gazdagodott. Ilyen elsöben is a kutatás ama nagy jelentőségü iránya, a melyet Flechsig honosított meg az anatomiában. Inkább technikai színezetú, de eredményeiben nem kevésbbé fontos a $W$ eigert-féle hæmatoxylin-festés.

$\mathrm{E}$ módszerekkel éltem én is jelen vizsgálataim alkalmával, hozzácsatolván azonban még egy harmadikat, t. i。az összehasonlító anatomia módszerét. Kutatásaimat ugyanis - bár fökép az emberre vonatkoznak - kiterjesztettem több állatfajra is, s így összehasonlítás útján, szélesebb alapon igyekeztem a vitás kérdéseket megfejteni.

Átvizsgáltam elöször is az ember gerinczvelejét, még pedig 28 cm., 30 cm., 32 cm., 36 cm., 45 cm. hosszú magzatét, újszülöttét és felnőtt emberét, továbbá a macska, házinyúl, tengeri malacz és egér gerinczvelejét, még pedig különbözö fejlettségü állatokét a velöfejlödés kezdetének idejétöl a befejezéséig. Végül még felkutattam a kifejlödött kutya gerinczvelejét is.

Mielőtt így szerzett tapasztalataim közlésére térnék át, legyen szabad néhány ujabb kutató nyilatkozatait a szóban forgó tárgyról elmondanom.

Minthogy az észleletek több pontra nézve igen széttérnek, nem volna könnyủ feladat, ismereteink jelen állását rövid áttekintés keretébe összefoglalni, s így helyesebbnek vélem, ha az utóbbi időben felmerúlt nézeteket egyszerúen felsorolom, közöltetésök sorrendje szerint.

Krause $^{*}$ ) leírja, hogy a hátulsó gyökerek, a gerinczvelöbe

*) Wilhelm Krause: Allgemeine und mikroskopische Anatomie. Hannover, 1876. 389. lap. 
hatolva, három esoportra oszlanak: medialisra, középsöre és lateralisra. Amaz a Burdarch-féle nyalábokba ereszkedik, e két utóbbi a Rolando-féle állományon halad át, délkörszerä hajlásokkal. A medialis esoport rostjai a Burdach-féle nyalábokból a szürke állományba lépnek s részben az elülsö szarvakba és elülső eresztékbe, részben pedig a hátulsó ereszték útján a túloldali hátulsó szarvakba követhetők. A középső csoport a Rolondo-féle állomány elött fekvő hosszanti nyalábokba hajlik át; e nyalábokból szakadatlanúl rostok válnak le, a melyek szintén az elülsö szarvak szürke állományában érnek véget. Az oldalsó csoport végződéséröl Krause esak annyit mond, hogy rostjai az elülsö szarvak felé haladnak, de csak a hátulsó határukig követhetők.

Schwalbe ${ }^{1}$ ) csak medialis és oldalsó részt ismer. Amannak rostjai egy darabig a Burdach-féle nyalábokban járnak, majd a szürke állományba térve az elülső szarvak legszélsö sejtjei közé, a Clarke-féle oszlopokba s az elülső eresztékbe mennek. A lateralis csoport egy része a hátulsó szarvak rosthálózatában, az elülső szarvakban s az elülsö eresztékben vész el; más része hosszanti irányba térve, a hátulsó szarvak ismert nyalábjait alkotja. E nyalábok rostjainak végződéséröl Schwalbe nem nyilatkozik.

Takács $\left.{ }^{2}\right)$ a hátulsó gyökerek gerinczvelöbeli darabját szintén két részre osztja fel, de e felosztásnál más szempontok szerint jár el, mint Schwalbe; az egyik esoportba azokat a rostokat foglalja össze, a melyek a szürke állományba mélyednek, a másikba azokat sorozta, a melyek be- és kifelé a fehér állományba hajlanak fel. Az elöbbi esoport rostjai a Clarke-féle oszlop sejtjeiben végződnek; az utóbbiakéi belépési helyök felett kisebbnagyobb távolságban betérnek a hátulsó szarvak szürke állományába. Az elülsö szarvakkal való kapesolatot, a gerinczvelö anatomiájának egyik legbiztosabb tételét, Takáes nem említi.

\footnotetext{
$\left.{ }^{1}\right)$ Dr. Gustav Schwalbe: Lehrbuch der Neurologie. Erlangen, 1881. 359. lap.

$\left.{ }^{2}\right)$ Takács Endre: A hátulsó gyökrostok lefutása a gerinczagyban; a gerinczagy hátsó részén lévő fehér állomány felépúlése és kóros változása (tabesnél). Orvosi Hetilap. 1887. 26. lap.
} 
Lissauer $\left.{ }^{1}\right)$ a gerinczvelő anatomiáját fontos fölfedezéssel gyarapította, avval t. i. hogy a hátulsó gyökerek kétféle idegrostokból állanak, durvákból és fínomakból. Ez észleletét valamennyi azóta megszólalt szerzö megerösíthette. A fínomak a gerinczvelöbe érve, azonnal kifelé hajolnak s a Rolando-féle állomány s a gerinczvelö kerülete közt egy kis, jól elhatárolt nyalábbá gyülnek össze, melyet Lissauer széli zonának (Randzone) nevez. Ebben egy ideig hosszant járnak, de elöbb-utóbb vízszintes irányba térnek át, s áthaladva a Rolando-féle állományon, a homorúságában fekvö fínom rosthálózatba mélyednek. E hálózat útján a hátulsó szarvak idegsejtjeit keresik fel e rostok s bennök végzödnek is. - Az erös idegrostok medialis és lateralis esoportra hajolnak szét. A medialis rostok egy ideig a Burdach-féle nyalábokban futnak, majd a szürke állományba térve, az elülső szarvak oldalsó sejtjeihez s az elülső eresztékbe követhetők (a Clarke-féle oszlopok sejtjeivel való összeköttetés elkerúlte Lissauer figyelmét). A lateralisok a Rolando-féle állományt átszelve, részben hosszanti nyalábokká sorakoznak, részben tovább mennek elöre. A tőle felfedezett "széli zona" kórtudományi jelentőségét Lissauer több tabeses gerinczvelö leírása kapesán világítja meg. Dolgozatának e nem kevésbbé értêkes részével nem foglalkozhatom e helyütt s csak azt emelem ki belöle, hogy e nyaláb tabesben mindig elfajúl.

Bechterew ${ }^{2}$ ) megerösíthette Lissauer észleletét, hogy a hátulsó gyökerek erös és fínom rostokból állanak, valamint hogy azok medialis, ezek lateralis fekvésüek s hozzátehette még, hogy a durvább rostok elöbb velösödnek, mint a fínomak; amazokat $25 \mathrm{~cm}$. h. magzatokban, emezeket $31-35 \mathrm{~cm}$. hosszúakban találta velös állapotban. Kiemeli, hogy észleletei szerint a hátulsó gyökerek valamennyi rostja magának a gerinczvelönek szürke állományában ér véget; félbeszakíttatás nélkủl egy se megy fel

$\left.{ }^{1}\right)$ Dr. Heinrich Lissauer: Beitrag zum Faserverlauf im Hinterhorn des menschlichen Rückenmarks und zum Verhalten desselben bei Tabes dorsalis. Archiv für Psychiatrie. Bd. XVII. 1886. 377. lap.

2) Wilhelm Bechterew: Ueber die hinteren Nervenwurzeln, ihre Endigung in der grauen Substanz des Rückenmarkes und ihre centrale Fortsetzung im letzteren. Archiv für Anatomie und Physiologie. Anat. Abth. 1887. 126. 1. 
az agyvelöbe. A medialis esoport rostjai részben a Burdach féle nyalábba ereszkednek, a melyből - miután benne egy darabon fölfelé haladtak - a szürke állományba mélyednek, részben egyenesen áttörnek a Rolando-féle állományon. Sorsuk a következö : némelyek az elülső szarvak rosthálózatában végződnek; egyesek átlépve az elülső eresztéken, az elülső alapnyaláb útján a túlsó oldali elülső szarvban érnek véget, mások a Clarke-féle oszlopok sejtjeivel kapesolatosak. A fínom rostú oldalsó esoport egy darabon felfelé halad a Lissauer zonája képében, majd átáramolva a Rolando-féle állományon, az elötte levő apró idegsejtekkel lép kapesolatba. Némelyek egyenesen az elülső szarvak oldalsó sejtesoportjáig követhetők. A hátulsó ereszték Bechterew megfigyelései szerint leginkább a szürke állomány két felét öszszekapesoló rostokból áll; a hátulsó gyökerek rostjai közül csak a lateralisoknak van részök a képezésében.

Obersteiner ${ }^{1}$ ) a hátulsó gyökerekben szintén erös és fínom idegrostokat különböztet meg. Ez utóbbiak legszélsőbb fekvésüek, elsöben a Lissauer zonáját alkotják s azután betérnek a Rolando-féle állományba; további járásukról Obersteiner nem tesz közlést. Az erösebb idegrostok medialis és lateralis esoportra válnak szét. A medialisok egy darabig hosszant haladnak a Burdach-féle nyalábokban, majd betérnek a szürke állományba; egy részök a Clarke-féle oszlopok sejtjeiben, más részök a hátulsó szarvak orsó-alakú sejtjeiben végződik. A hátulsó ereszték rostjai valószínúleg nem egyenes folytatásai a hátulsó gyökereknek. A lateralis csoport, a Rolando-féleállományon áthaladva, a szürke állományba merủl; alkotó részei közúl egyesek tovább mennek elöre, mások hosszanti irányba térnek, némelyek "talán" az itt fekvő idegsejtekben végzödnek.

E leírásokban több megegyezö vonásra akadunk. Csaknem minden ízében eltérő, önálló eredményre jutott Edinger ${ }^{2}$ ), a ki az összehasonlító anatomia észleletei s a kórtudomány tapasztalatai összekapcsolása útján igyekezett a hátulsó gyökerek

$\left.{ }^{1}\right)$ Dr. Heinrich Obersteiner: Anleitung beim Studium des Baues der nervösen Centralorgane. Leipzig und Wien, 1888. 187. lap.

$\left.{ }^{2}\right) \mathrm{Dr}$. Ludwig Edinger: Ueber die Fortsetzung der hinteren Rückenmarkswurzeln zum Gehirn. Anatomischer Anzeiger IV: Jahrg. 1889. 121. 1 . 
járását, végzödését megfejteni. Leírása szerint a gyökerek mindjárt a gerinczvelöbe való ereszkedésök után két részre : medialis és lateralisra válnak szét. A medialis csoportnak egy része a Clarkeféle oszlopokba tér, más része a hátulsó nyalábokban felfelé tart $\mathrm{s}$ csak a nyúltvelöben, a hátulsó nyalábok ismert magvaiban végződik. Az elülső szarvakban való végződésről Edinger mit sem szól. A lateralis rész áttör a Rolando-féle állományon s elötte egy fínom ideghálózatban vész el, melynek hézagjaiba vannak a hátulsó szarvak idegsejtjei ágyazva. Edinger valószinünek tartja, hogy e rostok valamennyien összefüggnek e sejtekkel. Itt azonban esak provisorius végzödésöket látja. E sejtek tájékáról Edinger szerint számos idegrost hajlik elöre az elülső ereszték felé, rajta átlép, az elülsö-oldalsó alapnyalábban felfelé tart, s a nyúltvelö hurokrétege útján a mesencephalonban végzödik. Lissauer tehát a rostok legnagyobb része végződését nem a gerinczvelöben, hanem az agyvelßbben keresi; nagyobbára ú. n. "hosszú pályá"-t képeznek. E tekintetben felfogása leginkább ellenkezik a Bechterewével, a ki épen az ellenkezöt állítja. Edinger leginkább a hátulsó gyökerek sértésére beálló felhágó elfajulásokra hivatkozik, de újabban kétségtelenné vált, hogy a degeneratio tovább terjedhet az idegrostokon, ha azokat útjokban idegsejtek szakítják is félbe : az idegsejt az elfajulásnak nem állja mindig útját.

\section{A hátulsó gyökerek csoportjairól általában.}

A hátulsó gyökerek, mihelyt a gerinczvelöbe nyomúltak, szétoszolnak. E szétszóródás kétfelé megy végbe: a gerinczvelö hosszában s a vízszintes síkban. A függöleges eloszlás nem szolgáltat alkalmas alapot a hátulsó gyökerek további felosztására ; a haránt síkban való széttérés ellenben felhasználható erre. A széthajló rostok iránya szerint három esoportot különböztetünk meg: medialist, középsöt és lateralist.

Ezek közűl a medialis úgy az emberben, mint az eddig megvizsgált állatokban a legerősebb : ez teszi a hátulsó gyökerek főrészét. A középsö az ember gerinczvelejében gyengébben, egyes állatokon erösebben van kifejlödve. Legszembeötlöbb e csoport 
a tengeri malaczban, a melyben a gyökérrostok széthajlás a medialis és középső esoportra első tekintetre is szembetünik, de felismerhető e feloszlás valamennyi állat s az ember gerinczvelején is, kivált ha azt a fejlödéstan nyomán kutatjuk. A lateralis csoport a két elsőhöz képest úgyszólván elenyészöen csekély. Legerősebb fejlettségben még az emberben találkozunk vele. Valamivel gyengébb már a ragadozó állatokon (kutya, macska). A házi nyúl, tengeri malacz és egêr gerinczvelejében már oly jelentéktelen, hogy esak figyelmes vizsgálatra ismerhetjük fel némi nyomait. E esoportról a legutóbbi időkig épen rostjainak csekély száma és fínomsága miatt nem is volt tudomásunk; Lissauer mutatta meg néhány évvel ezelött a Weigert-féle festés segélyével. Obersteiner az oldalsó rostokat nem is foglalja külön csoportokba össze, hanem egyszerüen csak "leglateralisabb rostok" néven szól rólok, s lateralis csoportnak a mi középsőnket nevezi. $\mathrm{Az}$ összehasonlító anatomia esakugyan megokolttá teszi ez eljárást $\mathrm{s}$ hogy e rostokat mégis külön csoportba soroztuk, azt azért tettük, mivel az emberben, érdeklödésünk fötárgyában, mégis számbajövő nyalábot tesznek, a mely - mint azt Lissauer kiderítette, - a gerinczvelö megbetegedéseiben (tabes) önálló szerepet visz. Ez bírta Bechterew-et is arra, hogy a gyér rostokat lateralis esoport néven a hátulsó gyökerek valamennyi többi rostjaival (medialis esoport) szembe állítsa.

A három csoport egymástól több tekintetben eltér. Nevezetes különbség van köztük annyiban, hogy a medialis és középső csoport leginkább erősebb, a lateralis pedig fínom idegrostokból áll. Egy elöbbi dolgozatomban *) megmutattam, hogy a velösödés sorrendje szorosan összefügg a rostok vastagságával ; minél vastagabb valamely idegrost, annál korábban nyeri velöshüvelyét. E tétel újabb bizonyítékát látjuk a hátulsó gyökereknél is. A medialis és középső csoport elöbb velösödik, mint az oldalsó; a két első velösödése közt is van némi idöbeli eltérés : a medialisban legelöször indúl meg e folyamat, de csakhamar megkezdődik a középsőben is. Így találtam ezt nemesak az em-

*) Dr. Michael v. Lenhossek: Untersuchungen über die Entwickelung der Markscheiden und den Faserverlauf im Rückenmark der Maus. Archiv für mikroskopische Anatomie. Bd. XXIII, 1889. 94. 1. 
berben, de valamennyi tölem megvizsgált állatban is. Az embernél a velöshüvelyek képzödése a medialis esoportban $28 \mathrm{~cm}$., a középsőben $32 \mathrm{~cm}$., a lateralisban $45 \mathrm{~cm}$. hosszú magzatoknál indúl meg. A hátulsó gyökerek egyáltalában késöbb kapják velöshüvelyeiket, mint az elülsök. Ez utóbbiak pl. már $36 \mathrm{~cm}$.-nyi magzatokon teljesen velösek, a hátulsók még újszülötteken sem ilyenek egészen.

$28 \mathrm{~cm}$. hosszú emberi magzatban a hátulsó gyökerekben igen csekély a velös rostok száma. E rostok a gyökér extramedullaris darabjában egyenletesen vannak szétosztva, a gerinczvelöben azonban mind befelé tartanak. Valamenyien a Burdach-fóle nyalábba térnek s benne egy darabon hosszant járnak, majd a szürke állományba mélyednek be, a melyben egyenesen elöre tartanak, a Clarke-fele oszlopoktól kifelé. Számuk oly esekély, hogy alig látni néhányat egy-egy szeleten. Egyesek a Rolando-féle állomány medialis részén hatolnak át.

$36 \mathrm{~cm}$.-nyi magzaton jelentékeny haladás észlelhetö a hátulsó gyökerek velösödésében. A medialis rostok esaknem egészen velösek már. A középső csoport elemei is jó részt azok; e rostok egy vagy több vaskos nyaláb képében egyenesen átmennek a Rolando-féle állományon s elötte hosszanti irányba hajolnak át, erős, a színtelen alapállományon élénken elötünö nyalábokat képezve.

$45 \mathrm{~cm}$. hosszú magzatban úgy a medialis, mint a középső szakasz velös rostjai tetemesen megszaporodtak. A velösödés elsö nyomai már az oldalsó csoportban is mutatkoznak; a Lissauer-féle széli zonában néhány elszórt sötét pont jelenik meg, valamint a Rolando-féle állomány homorúságában is. Bechterew azt állítja, hogy az oldalsó esoport már 31 -35 cm.-nyi magzatokban velös. Én meg $36 \mathrm{~cm}$. hosszúakban is tökéletesen velötlennek találtam.

Újszülött gyermek gerinczvelejében a két belsö csoport teljesen készen áll, a lateralis is közeledik a végleges állapothoz, de velös rostjainak száma még nines akkora, mint felnött emberben; e rostok egy része tehát csak a születés után nyeri velöshüvelyét.

Hogy a velösödés sorrendje az állatokon sem más, mint az emberben, az kitünik a következőkböl. 
Csaknem egészen érett macska-foetusban a hátulsó gyökerok extramedullaris darabjában, söt a Rolando-féle állomány mögött befelé tartó szakaszában is sok a velös rost, de a szürke állományba közủlök alig egy pár folytatódik. A legmedialisabb rostok helyén észlelhetni 1-2, a hátulsó szarvba térö fekete fonalat, vagy néha egyet-egyet, a mely a Rolando-féle állomány legbelső részén lép át. E rostok mindig a Clarke-féle oszlopoktól oldalt haladnak elöre. 3 napos macskán nem sokat haladt a velösödés: mindössze is ugyan e rostok száma lett valamivel nagyobb. - A 7 napos macska gerinczveleje rendkívül tanulságos. A medialis esoport elemei derekasabban velösek, s egyetlen állatnál, egy gerinczvelön sem láttam meggyőzöbben, hogy e rostok az elülső szarvakhoz haladnak. A középsö esoport, hosszanti nyalábjaival együtt, félig velősnek nevezhetö; érdekes, hogy a Lissauer-féle zona is foglal már néhány velös rostot magában. Nem sokkal fejlettebb a 15 napos macska gerinczveleje. A Rolando-féle állományt beborító terület rostpontjai valamivel megszaporodtak, de még mindig megszámlálhatók; finom, elszórtan fekvő idegrostok ezek, csoportjok éles határ nélkül csatlakozik ama velös rostokhoz, a melyek az ez időtájban még velötlen pyramis-nyalábok területén láthatók, valamint a határréteg finom nyalábjaihoz.

A legfiatalabb tengeri malacz, a melynek gerinczvelejét felkutathattam, újszülött volt, pedig ilyennél a velösödés a gerinczvelö minden pontján - a pyramis pálya kivételével - esaknem teljesen befejezödött már. A hátulsó gyökerek legnagyobb része is velösnek nevezhetö, mindössze is esak annyi különbség a teljesen érett állathoz képest, hogy a lateralis esoport rostjainak száma esekélyebb még valamivel, mint ennél. - A viszonyok itt mások, mint az embernél. A középső csoport igen erös, a hátulsó szarvak hosszanti nyalábjai élesen lépnek elő s kifelé határ nélkül szegödnek az oldalsó nyalábok legbelső részéhez. A Rolando-féle állomány csak a gerinczvelö kerületéig ér; hátulsó szélét esak gyenge rétegben fedik a "széli zona" finom rostjai.

3 napos egér gerinczvelejében a hátulsó gyökerek szabad darabja néhány szétszórt velös rostot tartalmaz, e rostok követhetök a Burdach-féle nyalábokba is, de a szürke állományba 
már nem. Ugyan-e stadiummal találkozunk az 5 napos egérben. A 9. napon a medialis esoport elemei közủl sok bír már velöshüvelylyel, sőt a középső csoport rostjai közúl is néhány. A medialis rostok részben a Burdach-féle nyalábok hosszabb útját vála`ztják a szürke állományba való betérésre, részben a Rolando-féle állomány medialis szakaszán haladnak át egyenesen. A 11-dik naptól a 14-kig nagy a haladás : a középső rész hosszanti nyalábjaival együtt immár egészen velös. Oldalsó csoportja az egérnek alig van. A széli zona analogonját az oldalsó nyalábok hátulsó zugában ismerhetjük fel; e területen már a 14. napon finom velős rostok tünnek elö, tehát a lateralis csoportban is megindúlt már a velösödés; de mivel e terület még a 18. napon sem bír annyi velös rosttal, mint a teljesen kifejlödött állatban, felvehetjük, hogy az még ezidötájban sem fejeződött be. - 25 napos egérben a viszonyok e tekintetben is elérték a végleges állapotot.

\section{Összefoglalás.}

1. A hátulsó gyökerek a gerinczvelöbe lépve, három esoportra oszlanak szét: medialisra, középsöre és lateralisra.

2. A medialis a legerősebb, a lateralis a leggyengébb a három közül; egyes állatokban (házi nyúl, tengeri malacz, egér) ez utóbbinak alig találjuk nyomait.

3. A medialis és középső erősebb idegrostokból, az oldalsó finomabbakból áll.

4. A velösödés úgy az emberen, mint az átvizsgált állatokban belülről kifelé történik; legelöbb a medialis csoport velösödik, azután a középsö, s csak hosszabb idököz múltán lesz a lateralis is velössé.

5. A velőképződés e sorrendje összefügg a rostok erősségével.

A következökben egyenkint veszszük szemügyre a három esoportot.

\section{Medialis csoport.}

Az emberben a hátulsó gyökerek a Rolando-féle állománynyal szemközt, még pedig a közepénél valamive] beljebb lépnek 
be a gerinczvelöbe. Mivel ez állomány az emberben nem ér a gerinczvelő kerületéig, hanem attól a széli zona által választatik el, a hátulsó gyökerek nem oszlanak mindjárt szét, mint azt a legtöbb állatban találjuk, hanem egy kis darabon elöre tartanak, a széli zonát kisebb medialis és jóval nagyobb lateralis részre osztva fel s csak a Rolando-féle állomány hátulsó széléhez érve válnak szét kehelyszerúen a részeikre.

$\mathrm{Az}$ erős medialis esoport két útat választ. Nagyobb része befelé hajlik, betér a Burdach-féle nyalábba, benne egy ideig hosszant jár, de elöbb-utóbb kilépve belöle, a hátulsó szarvak szürke állományába hajlik be. Kisebb része a Rolando-féle állomány medialis harmadán megy át.

A medialis csoport elemei tehát már útjok első szakaszában két részre válnak szét : $a$ ) hátulsó nyaláb-rostokra és $b$ ) egyenes rostokra. Az elöbbiek, mint emlitettem, nagyobb számmal vannak az utóbbiaknál. A felosztás aránya egyébiránt ingadozó, nemesak a medialis esoport két része, hanem a medialis s a középsö csoport között is. A viszony kölesönösen kiegészíto közöttük, a mennyivel gyengébb az egyik, annyival erösebb a másik.

A Burdach-féle nyalábokhoz tartozó rostok a Rolando-féle állomány hátulsó szélénél hirte!en meghajolnak, s ez állomány széléhez ragaszkodva befelé, majd elöre tartanak, ívalakú járással. Egy darabig követhetök e rostok a harántszeleten, de csakhamar hosszanti irányba térnek át.

A Burdach-féle nyalábokon figyelmes vizsgálatra a gerinczvelö minden pontján három részt különböztethetünk meg. Legjobban látható e felosztás az ágyéki, legkevésbbé a háti részen. $\mathrm{Az}$ a terület, a mely közvetetlenúl a hátulsó szarvak mellett fekszik, a besugárzó rostok zonájának nevezhetb. Van ezenkívül egy elülsö, meg egy hátulsó zona.

A besugárzó zona félholdalakú, szegélyszerü terület; belül csaknem a középvonalig, illetve a Goll-féle nyalábig terjed, ezt azonban el nem éri, úgy hogy az elülsó zona a hátulsóval vékony híd útján összefüggésben marad; elöre és hátrafelé határai elmosódnak. A hátulsó gyökerek belépése helyétơl a hátulsó szarvak medialis széle mentén addig a pontig tart, a hol a szürke állományba hajló gyökérrostok közül a legmediálisabb fekszik. 
E zonában gyölseredzik valamennyi a hátulsó szarvakba besugárzó rost : ezért láttam el az említett névvel. A másik két zonától a következő sajátságok révén üt el : rostjai a gerinczvelö legtöbb pontján nem járnak szigorúan hosszant, hanem részint ferdén, összefonódva halađnak, részint pedig vízszintes, ívszerü járást tüntetnek fel. Az ágyéki részben találkozunk az ívrostok leghosszabb darabjaival; néha a mediális esoport egy-egy rostját a belépése helyétöl e zona egész területén át egyenesen a hátulsó szarvba követhetjük. Ez azonban ritkaság, legtöbbször félbe vannak szakítva e rostok. A háti szakaszban az ívalakú rostok egészen hiányzanak, a besugárzó rostok is igen rövid gyökerekkel erednek. E szakaszban leginkább a gliasövények összehajlása teszi e zona ismertető jelét. E sövények t. i. a gerinczvelö minden részén igen jellemzö járásuak e zonában; sugárszerüen hajolnak ugyanis össze a hátulsó szarvaknak közvetetlen a Rolando-féle állomány elötti pontja, vagyis ama szakasza felé, a melybe a mediális csoport rostjai belépnek. Irányuk tehát ugyanolyan, mint magoké e rostoké; elgondolható, hogy elrendezödésöket e rostok hasonló járása okozza. A nyaki részben megint élesebben tünnek elö az ívjárású rostok, de korántsem oly mennyiségben, mint az ágyéki darabon.

De megokolttá teszi e felosztást a velösödés sorrendje is, mert a középsö területen úgy látszik elöbb indúl meg e folyamat, mint a másik kettön. $28 \mathrm{~cm}$. h. magzaton a besugárzó rostok zonájában jóval több a velős rost, mint az elülsöben meg a hátulsóban, bár ezek sinesenek ilyenek híján. $30 \mathrm{~cm}$. hosszúban a velösödés elöre haladt, s a különbség kezd - kivált elöfelé - elmosódni, míg hátul még élénkebben lép elö. $36 \mathrm{~cm}$.-nyin az elülsö zonában is olyannyira neki indúlt a velöképződés, hogy az a középsővel immár egyszínü területté foly össze, söt helyenkint erősebb festődése által üt el attól ; a hátulsó zona azonban még jóval világosabb. $45 \mathrm{~cm}$. hosszúságnál az utóbbiban is gyarapszik a velö, de némi színbeli eltérés fennáll még mindig. Újszülött gyermekben mind a három zona elórte velössége teljét. A középső zona felnőtt ember gerinczvelején néha sötétebb festödésủ a másik kettönél, a mi rostjainak sürübb és fonatszerü elrendezödésével függ össze. E különbséget azonban igen gyakran hiába keressük. 
Itt van helye annak, hogy felfogásomat e három zona jelentőségéröl elmondjam. Megjegyzem, hogy - mint alább még bövebben megmutatom - e felosztás több állatban is meg van.

Véleményem szerint e besugárzó zóna tartalmazza a nyaki és ágyéki részben a Burdach-féle nyaláb rövid rostjait, azaz azokat a gyökérrostokat, a melyek belépésök után esakhamar, legtöbbször talán még ugyanazon idegszelvényben, a szürke állományba mélyednek. Az elülső és hátulsó zona ama rostok pályája lehet, a melyek a hátulsó gyökerekböl a Burdach-féle nyalábokba ereszkedve, terjedelmes darabon járnak a gerinczvelö hosszában s esak jóval magasabban vagy mélyebben, mint a hol a gerinczvelöbe léptek, hajolnak be a hátulsó szarvakba, a mikor persze nekik is a besugárzó zona rövid rostjai közé kell keveredniök. Láttuk, hogy a háti részen alig lehet ily zonát megkülönböztetni, a mit összeegyeztethetünk azzal, hogy e tájékon a hátulsó gyökerek gyengék lévén, a rövid rostok száma esekély s a hátulsó nyalábokat leginkább olyanok alkotják, a melyek mélyebb, vagy tán magasabb tájékokról jönnek'.

$\mathrm{Az}$ egész gerinczvelö szerkezetén tisztán felismerhetö a természet amaz igyekezete, hogy a gerinczvelöt egyöntetüvé tegye s lehetőleg elkerúlje a szelvényességet, a mely a belóle eredő gyökereken oly nagy mértékben nyilvánúl. E czélt úgy éri el, hogy a gyökerek útján belépö rostokat a gerinczvelö egy-egy nagyobb területére osztja szét. Az ideggyökerek, hosszanti irányba fordúlva, a magok szelvényökben, egyenletesen eloszolnak, söt talán benyomúlnak a szomszédos szelvények körébe is, a mivel egyúttal physiologiai kapcsolat is létesúl az egyes idegek középpontjai között. Ilyenféle, de nagyobb arányú "nivellálás» áll fenn a gerinczvelö terjedelmesebb szakaszai, a nyaki, háti és ágyéki rész között is. Hasonlítsuk pl. össze valamely háti ideg erősségét a plexus ischiadicus bármelyik törzsökének erösségével ; mennyivel jelentékenyebb e különbség annál, a mely a gerinczvelő háti és ágyéki részének átmérőiben nyilvánúl; a háti résznek az ágyéki duzzadáshoz képest jóval vékonyabbnak kellene lenni. Felfogásom szerint e kiegyenlítés a következőkön alapúl. Az ágyéki idegek gyökereinek egy része nem végződik az ágyéki szakasz szürke állományában, hanem 
felfelé megy a gerinczvelö háti darabjába (az elülső gyökerek az elülsö-oldalsó alapnyaláb, a hátulsók a Burdach-féle nyaláb elülső és hátulsó zonája útján) s itt végződik, egyenletesen szétoszolva az elülső szarvakban (elülsö gyökerek) s a Clarkeféle oszlopokban (hátulsó gyökerek), a mely utóbbiak a hátulsó gyökerek igen fontos végződési helyei gyanánt ismerhetök fel.

Lehet, hogy a nyaki duzzadás felöl a gyökerek rostjai részben lefelé tartanak; nagy részök bizonyosan fölfelé vonúl s a nucleus funiculi gracilis et cuneati-ban ér véget. A szürke állománynak a rögtöni végződés mellett túlságosan meg kellett volna duzzadnia. Nézetem szerint e vázolt felfogás magyarázza meg legjobban a Clarke-féle oszlopoknak és a hátulsó nyalábok magvainak helyzetét, jelentőségét.

Felosztásommal a fölfedezés érdemére nem tarthatok számot; ily szembeötlö viszonyok nem kerülhették el annyi gondos kutató figyelmét. A Burdach-féle nyaláboknak a szürke állománynyal érintkező részét már több szerző emelte lii "gyökérzona" néven; ez elnevezést azonban nem tarthatom helyesnek, mert véleményem szerint az elülső és hátulsó zona sem épül fel egyébből, mint a hátulsó gyökerek rostjaiból.

Bechterew ${ }^{1}$ ) a Burdach-féle nyalábokat szintén felosztja, de bennök esak két részt különböztet meg: hátulsó peripheriást, mely a hátulsó gyökerek belépése helyétől a Goll-féle nyalábokig terjed, s förészt, a mely már az 5-6-dik hónapban velös, míg az elöbbi ez időtájban még velőtlen. Bechterew peripheriás területe nyilván megegyezik a mi hátulsó zonánkkal, de fơrésze már a mi másik két zonánk summájával azonos. Feljebb kifejtettem, hogy e további felosztásomnak mi az alapja.

Obersteiner könyvében ${ }^{2}$ ) meglepetésemre egy a gerinczveló nyalábjait schémásan feltüntető rajzra akadtam (101. ábra), a melyen az elülsö zona, vagy legalább egy része meg van jelölve. A rajz magyarázatából az tünik ki, hogy Obersteiner e területet a Goll-féle nyalábokhoz számítja, egyébiránt csak annyit mond

1) W. Bechterew: Ueber die Bestandtheile der Hinterstränge des Rückenmarkes auf Grund der Untersuchung ihrer Entwickelung. Neusologisches Centralblatt, 1885. 31. 1.

2) Obersteiner : i, m 195. 1. 
róla, hogy "emez, a szürke ereszték homorúságában fekvő terület, úgy látszik, különös nevezetességgel bír».

A medialis csoport hátulsó-nyalábrostjai tehát a Burdachféle nyalábokba bocsátkozva, bennök rövidebb-hosszabb darabon hosszanti irányban járnak. A Goll- és Burdach-féle nyalábok magvaiban valószínüleg a leghosszabbak is véget érnek. A pyramis-kereszteződés tájékáról vett szeleten a Goll-féle nyaláboknak alig találjuk már nyomait, helyöket tökéletesen elfoglalta a nucleus funiculi gracilis. A Burdach-félék egy ideig még megmaradnak félholdalakú, a nucleus funiculi cuneati-t beborító nyaláb képében; fölfelé követve azonban azt látjuk, hogy e nyaláb mind keskenyebb lesz, rostjai közé szürke vagy kocsonyás állományból álló csomók, a Burdach-féle mag leszakadt részei (nucleus funiculi cuneati externus, Schwalbe) helyezkednek s végúl a nyelvalatti ideg magvai tájékán végkép eltünik.

A Rolando-féle állományon áthaladó rostok egyenesen belépnek a szürke állományba. A Burdach-féle nyalábokat alkotók a Rolando-féle állomány elött szép ívalakú hajlással több nyalábban behajolnak a hátulsó szarvakba, találkoznak itt az egyenes rostokkal, s velök tömött esoporttá egyesülnek. $\mathrm{Ez}$ az erös nyaláb már most rövid darabon egyenesen elöre tart, de esakhamar ismét szétválik két csoportra. Nagyobb része az elülső szarvak felé megy, megkerülve oldalt a Clarke-féle oszlopokat, kisebb része ez utóbbiakban, vagy a hol hiányzanak, a megfelelö magrakban (Stilling-féle magvak) végződik. Ez utóbbi csoport a medialisabb fekvésủ rostokat tartalmazza. A két esoport közt különbség van a velösödés idejére nézve is: az elülsö szarvakhoz menö rostok elöbb velösödnek, mint a Clarke-féle oszlopokhoz tartozók. $28 \mathrm{~cm}$.-nyi magzatbana mediális csoport ama néhány rostja, a mely már velős, mind a Clarkeféle oszlopoktól oldalt fut az elülsö szarvak irányában; $36 \mathrm{~cm}$. hosszúban ez oszlop rostjai is velösök már.

A mediális esoport vonatkozása az elülső szarvakhoz kétségtelen: itt van rostjaik fövégződése. E rostok nem tartják meg útjokban tömött elrendeződésöket; előre haladó nyalábjok már a Clarke-féle oszlopok tájékán, a hátulsó ereszték színvonalán ecsetszerüen szétoszlik. A hosszanti szeleten valóságos fonatot látni e helyen, a melyłen azonban legtöbb a vízszintes rost. 
Bár e szétszórodás e rostok további járásának megfigyelését megnehezíti, mégis biztosan meghatározható az. Töredékeik ugyanis az elülső szarvak felé vezetnek. A sejtek közé legtöbbször e rostdarabok nem követhetők, a mennyiben már a mögöttük fekvő rosthálózatban vesznek el. Némely szeleten azonban meglepö tisztasággal emelkedik ki egy-egy nyaláb, a mely, a nélkül hogy szétforgácsolódnék, egyenesen a leglateralisabb sejtek közé lép. Ezekkel tehát a medialis csoport rostjainak egy része valószínüleg direct összefügg, míg a többi rostra nézve csak a rosthálózatba való mélyedés mutatható ki.

Legszebben tanulmányozható mind ez az újszülött gyermek gerinczvelején, a melyen a medialis csoport már tökéletesen velős, míg a szürke állomány rosthálózata, mely járásuk követését megnehezíti, még nem érte el későbbi sürüségét.

Hogy a Clarke-féle oszlopok a hátulsó gyökerek fontos végződési helyei, azt a legtöbb szerző elismeri. Legjobban tanúlmányozhattam ez összefüggést $36 \mathrm{~cm}$. hosszú magzaton. A medialis esoport belsö, kisebb része, mihelyt a Burdach-féle nyalábból a szürke állományba tért, hátulról bemélyed a Clarke-féle oszlopokba és sejtjeik közt oszlik el. E sejtek legtöbbnyire orsóalakúak, elülröl hátramenö tengelylyel; de ez az alak csak a gyökerek belépése helyén kifejezett, más szeleteken a sejtek inkább köralakúaknak mutatkoznak. A magyarázatot hosszanti szeletek adják meg. Ezeken azt észlelhetni, hogy e hosszúkás sejtek iránya convergál ama pont felé, a hol a Burdach-féle nyalábból egy-egy erösebb rostesoport ereszkedik a Clarke-féle oszlopokra. Fekvésök tehát legtöbbször párirányos a gerinczvelö tengelyével - a mint azt Obersteiner is leírja s így a legtöbb szeleten köralakú harántszeletökkel találkozunk. A nagyobb sejtek száma egy-egy szeleten és oldalon 5-8.

A hátulsó gyökerek rostjainak összefüggése e sejtekkel bizonyos: néha egyenesen megfigyelhető. Valóságos "bátulsó gyökér-sejtek" ezek. Ez összefüggést bizonyítja a következö, nem ritkán tehetö észlelet is : megesik, hogy a Clarke-féle osz. lopok sejtjei közúl néhány — rendszerint 2-3 egy szeleten leválik e magvakból s hátrább helyezkedik, a mediális csoport rostjai közé, a melyekkel ez orsóidomú sejtek párirányos fekvésüek. E levált elemeket legtöbbször a szürke állomány hatá- 
rán leljük, de találkozhatunk velök a Burdach-féle nyalábok besugárzó zonájában is. Ez az észlelet annyiban érdekes, hogy némi világot vethet a Clarke-féle oszlopok s a gerinczvelöi dúczok jelentöségére. Freud-tól ${ }^{1}$ ) indúlt ki az az a nézet, hogy e dúczok nem egyebek, mint a gerinczvelő szürke állományának elöre tolt, levált részei. E felfogást támogatta Rattone ${ }^{2}$ ) ama fölfedezése, hogy néha a hátulsó gyökerek rostjai közt egész darabjokban a gerinczvelötöl a dúczig szétszórtan idegsejtek találhatók. Bizonyítéka e felfogásnak a jelen észlelet is; a Clarke-féle oszlopokból kilépett sejtek nyilván csak folytatásai a Rattone-féléknek s velök együtt lánczszerü összeköttetést formálnak ez oszlopok s a gerinczvelöi dúczok közt, a melyek e felfogás szerint analogok volnának egymással. Igaz, hogy a gerinczvelöi dúczok idegsejtjei a kétéltüektöl fölfelé csak egy nyújtványnyal bírnak, a mint azt legelöször Kölliker ${ }^{3}$ ) tanította, s ebben elütnének a Clarke-féle oszlopok nyilván legalább is kétsarku sejtjeitöl. De Ranvier ${ }^{4}$ ) ama fölfedezése, hogy e nyújtvány elöbb-utóbb ketté oszlik, s a, már Ranvier-töl is gyanított, de legelöször tölem ${ }^{5}$ ) bebizonyított tény, hogy a nyújtvány két szára közül az egyik a gerinczvelö, másik a kerület felé megy - e különbséget csak látszólagossá teszi s így felfogásunk elé akadály nem gördül. Fontos még e tekintetben $H i{ }^{6}$ ) ama, legújabban közölt megfigyelése is, hogy $4-5$ hetes

1) Sigmund Freud: Ueber Spinalganglien und Rückenmark des Petromyzon. Wiener akad. Sitzungsberichte. Bd. 78. 1878. Abthg. 3. 81. 1.

$\left.{ }^{2}\right)$ Gustav Rattone: Sur l'existence de cellules ganglionnaires dans les racines postérieures des nerfs rachidiens de l'homme. Internationale Monatsschrift f. Anatomie und Histologie, 1884. 53. lap.

$\left.{ }^{3}\right)$ Albert Kölliker: Die Selbstständigkeit und Unabhängigkeit des sympathischen Nervensystems. Zürich, 1844. 21. lap.

$\left.{ }^{4}\right)$ Louis Ranvier: Des tubes nerveux en $T$ et de leur relations avec les cellelus ganglionnaises. Comptes rendus de l'Academie des sciences, 1875. Tôme 81, 1274. 1 .

$\left.{ }^{5}\right)$ Lenhossék Mihály: Adatok a gerinczagyi dúczok ismeretéhez. Értekezések a természettudományok köréből. Kiadja a m. tud. Akadémia. XV. kötet. 1885. 15. szám. 78. lap.

$\left.{ }^{6}\right)$ Wilhelm His : Die ersten Nervenbahnen beim menschlichen Embryo. Uebersichtliche Darstellung. Archiv für Anatomie und Physiologie. Anat. Abthg. 1887. 374. lap. 
emberi embryók gerinczvelöi dúczaiban csupa kétsarkú, orsóalakú sejtek találhatók, a két nyújtvány kezdeti darabjai csak utóbb fonódnak össze egygyé. - Ime egy oly elmélet, mely a Clarke-féle oszlopok jelentöségét más úton igyekszik megfejteni, mint az a felfogás, a melyet fentebb vázoltam.

A hátulsó gyökerekkel való összefüggésre utal már a Clarke-féle oszlopok alakja is: legtöbbször körte-idomúak, vaskosabb elülső, vékonyabb hátulsó részszel, mely utóbbi megvékonyodva folytatódik a nyelökbe : a hátulsó gyökerek mediális csoportjába. Ez alak legszebben tünik elö 32 cm.-nyi magzatok gerinczvelején, a hol ez oszlopok alapállományában, a sejtek közt sok myeloid anyag rakódván le, e magvak egészökben igen élénken emelkednek ki halványabb környezetükböl.

Egyenesen kifelé, az oldalsó nyalábok irányában hajló "tengelyfonál-nyújtványt», a minöt Pick és Laura véltek észlelni, a Clarke-féle oszlopok sejtjein ritkán láthattam. Az oldalsó kisagyvelöi pályához menö rostok valószínüleg az elülső tengelyfonál-nyújtványból erednek. Erre utal e "vízszintes kisagyvelöi nyalábok" (Flechsig) ismert járása is : a Clarke-féle oszlopok elülső oldalán erednek, de alig hogy belölük kiléptek, hirtelen merész hajlással kifelé fordúlnak s azután harántosan kifelé tartanak az oldalsó nyalábok felé. Az oldalsó tengelyszál-nyújtványra tehát nines is szükség.

Számos kutató - az ujabbak közül Schwalbe, Lissauer és Bechterew - azt állítja, hogy a mediális csoport néhány rostja az elülső eresztékbe megy, a melynek útján az ellenkező oldali elülső szarvba jutna. Bár e pontra, épen mert oly kiváló szerzők nyilatkoztak ez összefüggés mellett, különös gondot fordítottam, a rostok ilyen járásáról sohasem tudtam meggyöződni, úgy hogy e vonatkozást tagadnom kell. Az elülső ereszték elemei az elülső szarvakból gyülnek össze, hátulról az ember gerinczvelejében egy rostja sem jön.

A hátulsó eresztékhez a mediális esoport azonban kétségtelenúl hozzájárul néhány rosttal. Mivel ez alkotó részeit leginkább a középsö esoportból nyeri, alább fogunk bövebben szólni róla.

A hátulsó gyökerek viszonya a Goll-féle nyalábokhoz igen 
nehezen dönthetö el. Egyik értekezésemben *) valószínünek nyilvánítottam azt a felfogást, hogy nem egyenes folytatásai a hátúlsó gyökereknek (Rossolymo, Bechterew), de kiemeltem, hogy e nyilatkozatom esakis mások közlésein, a kísérleti kórtudomány eredményein s nem saját megfigyeléseimen alapúl. Újabb tapasztalataim kissé megingattak e nézetben. Az emberben a commissura posterior igen gyenge fejlödésü s ugyancsak csekély ama rostok száma, a melyek belöle a Goll-féle nyalábokba ereszkednek, úgy hogy e nyalábok elemeit alig vezethetjük le más forrásból, mint a hátulsó gyökerekböl. A kérdés végleges megoldását további tapasztalataktól kell várnunk.

A macskában a medialis csoport rendkívül erős, a hátulsó gyökerek legnagyobb részét ez teszi, s csak kevés rost jut a másik két csoportra. A rostok részben a Burdach-féle nyalábok útján, részben a Rolando-féle állományon át jutnak a szürke állományba, a mely utóbbinak belsö $2 / 3$-át foglalják el; ez utóbbi rostok az elöbbieknél nagyobb számmal vannak. A Burdach-féle nyalábok három zonája itt is meg van, ép oly elrende. zödésben, mint az embernél. A középső zona ismertető jeleit a rostok ívszerü járása s a glia-sövények összehajlása teszi. A velösödés sorrendje is ugyanaz. 3 napos macskában a besugárzó zonában több a velö, mint a másik kettőben, de e különbség leginkább esak az ágyéki részen észlelhetö. A mediális csoportban igen kevés még a velős rost, mindössze egy pár fekete fonalat látunk, a melyek a Burdach-féle nyalábok középse̋ zonájából a szürke állományba hajolnak s a Clarke-féle oszlopoktól oldalt tartanak elöre. Az ez utóbbiakhoz menö rostok esak a 7-ik napon lépnek elö. Ez időtájban, mint már említettem, a gerinczvelö szeletei igen tanúlságos képeket szolgáltatnak. A mediális csoport hátulsó nyaláb-rostjai a külső egyenes rostokkal a Rolando-féle állomány elött délkörszerúen egy közös nyalábbá hajolnak össze, a mely - kissé kifelé tartva - elöre megy, de nem sokára fellazúl s az elülső szarvak centrális részébe ereszkedik be. A háti szakasz alsó s az ágyéki szakasz felső darabján a rostok legnagyobb része a gömbölyded Clarke-

*) Tenhossék: Untersuchungen über die Entwickelung der Markscheiden. 118. 1. 
D’̃ LENHOSSÉK MİHÁLY.

féle magvakban ér véget. 15 napos macskán ugyanezekröl gyöződhetünk meg. Némely szeleten rendkívül meggyőzően mutatkozik egy, a mediális csoportból eredő nyaláb, mely az elűlső szarvak oldalsó sejtrakásáig követhetö. A mediális eso. port végződése tehát ugyanaz, mint az emberben; hozzátehetem még, hogy itt se láttam soha egy rostot sem a hátulsó gyökerek elemei közúl a commissura anticába belépni.

Újszülött házinyúl gerinczvelejében a Burdach-féle nyalábok számos szétszórt rost-pontot tartalmaznak; a három zonát ez állatban hiába kerestem. A mediális részben számos velös rost van már, a melyek részint a Burdach-féle nyalábokból, részint a Rolando-féle állomány útján lépnek a hátulsó szarvakba. Az elöbbiek nem járnak oly szép ívalakban, mint az emberben, inkább egyenes, merev járásúak. Elöl a két esoport összehajlásából keletkezett nyaláb az elülsö szarv felé tart, de mielött azt elérné, kehelyszertien szétbomlik; rostjai az elülső szarvak hálózatában vesznek el. A Clarke·féle oszlopokba merïlők csak az 5-ik napon válnak ki.

A tengeri malaczban a hátulsó gyökerek belépési helye a Rolando-féle állomány közepénél küljebb esik. A mediális csoport egy része a Rolando-féle állomány kétharmadán hatol át, egyenlö közökben fekvő erős nyalábok képében, más része harántul befelé húzódik s a Burdach-féle nyalábokba merúl. E nyalábokon a három zona tisztán felismerhetö; a besugárzó zona a másik kettötöl ívszerü rostjai és sövényeinek sugárszerú összehajlása útján különbözik. E rostok azután csinos ívszerü járással behúzódnak a hátulsó szarvakba s az egyenes rostokkal délkörszerúen közös nyalábbá lépnek össze. E nyaláb egy darabon osztatlanúl halad elöre, de már a hátulsó ereszték színvonalán ecsetszerủen széttér; folytatásai az elülső szarvakba sugárzanak be. Legmediálisabb rostjainak néha olyan a járásuk, hogy nemcsak elöre, de egyúttal befelé is tartanak, mintha az elülső eresztékbe akarnának menni, figyelmes vizsgálatra azonban meggyözödünk, hogy elülsö végeik mégis csak kifelé hajlanak az elülső szarvak legmediálisabb részébe.

A Clarke-féle oszlopoknak más a helyzetök ez állatban, mint az emberben, nem fekszenek, mint ennél, a hátulsó szarv szabadon kinyúló darabjában, hanem elöbb, a commissura 
posterior színvonala elött. Gömbölyded alakúak s nagy orsóalakú, sagittalis fekvésű sejtekből állanak. A medialis csoport rostjai azokon a helyeken, a hol e magvak fejlodésök tetöpontját érik el, esaknem valamennyien beléjök ereszkednek. Alig találni tőlük oldalt egy-egy, az elülső szarvak irányába haladó rostot.

Az elülsö szarvak sejtrakásaikkal és rosthálózatukkal egy állaton sem emelkednek ki élesebben, mint a tengeri malaczban. Valóságos gömbölyded, a gerinczvelöbe ágyazott dúczok képében lépnek elö. E dúczokból elöl az elülső gyökerek, belül a commissura anterior rostjai erednek, hátul a mediális csoport széthajló elemei nyomúlnak beléjök. A gerinczvelö szerkezetének eme sarkalatos viszonyai némely szeleten csaknem a schema tisztaságával tünnek elö. A mediális csoportból az elülső szarvak oldalsó sejtjeihez menö tömött nyaláb itt is elöfordúl olykor. A rostok végződése tehát egészen olyan, mint az emberben: Clarke-féle oszlopok, elülsö szarvak rosthálózata és lateralis sejtjei.

Az egér gerinczvelejébe a hátulsó gyökerek épen a substantia gelatinosa közepével szemközt nyomúlnak be s rövid darabon befelé tartva, csakhamar szétválnak középső és mediális esoportra. Viszonyaikban nagy hasonlatosságot tüntetnek fel a tengeri malacznál leirottakhoz, csak a középsö csoport gyengébb aránylag valamivel, mint amannál. A mediális csoport fele vagy annál több rögtön áthalad a Rolando-féle állomány belső harmadán, másik része a Burdach-féle nyalábba bocsátkozik, s egy ideig a gerinczvelö hosszában járva, szintén a szürke állományba lép. A Burdach-féle nyalábok feloszlása zonákra, nem mutatkozik eléggé meggyözően. Az összetérö nyalábokból keletkezett vaskos törzsök a nyaki és háti részen egyenesen elöre tart, majd fellazúl s az elülső szarvakban végzödik. Ez állatban néha egyes tömött rostnyalábokat az elülső szarvaknak nemcsak lateralis, de medialis sejtjei közé is követhettem. Az elülső eresztékhez e rostok közűl egy se csatlakozik. A Clarkeféle oszlopok, a hol teljes fejlödésben vannak jelen, a mediális csoportnak jóformán valamennyi rostját lefoglalják. Az egérben a szürke állomány középponti részeiben csaknem minden magasságban szétszórt sejteket lebet látni, a melyeket Stiedá- 
$v a l^{1}$ ) "centralis sejtoszlop" néven foglaltam ossze. $\left.{ }^{2}\right)$ Leggyengébb e esoport a nyaki részen. A Clarke-féle oszlopok sem egyebek, mint e centralis oszlop erösebben fejlödött, kivált részei. Szá. mos szeleten úgy észleltem, mintha a mediális csoport legbelsö rostjai közúl egynéhány e csoport sejtjeihez menne, a min nem csodálkozhatunk, tudva, hogy a Clarke-féle oszlopok sejtjeivel egy jelentőségüek.

Jegyzet. A hátulsó gyökerek mediális esoportjának végzödése az elülsö szarvakban a gerinczvelö anatómiájának legbiztosabb tételei közé tartozik. Ebben esaknem valamennyi szerzö nézetei megegyeznek. Épen a legutóbbi idöben akadt azonban kutató, ki e végzödést ignorálja. A mediális csoport Edinger szerint részben a Clarke-féle oszlopokban érne véget, részben pedig felfelé vonúlna a hátulsó nyalábok útján egész a gerinczvelöi magvaiig. Edingert ez állításra leginkább a kórtudomány tapasztalatai bírták. Hivatkozik Singer, Schultze, Wagner és Kahler vizsgálataira, "a melyek által e tény immár végleg bebizonyíttatott».

Bármit következtessen is a kórtudomány a betegágynál, s a bonczoló asztalnál tett megfigyeléseiböl, az anatomusnak ahhoz kell ragaszkodnia, a mit lát: positiv észleleteit nem szabad, bogy egyéb szempontoknak alárendelje. E végzödés, mint említettem, sokkal biztosabb észlelet, mintsem hogy annak hitelét a pathologia bármily megfigyelése csorbíthatná.

Edinger felfogása szerint a Burdach-féle nyaláb esaknem egyedúl hosszában járó rostokból állana. De akkor nyilván alulról fölfelé fokozatosan gyarapodnia kellene, pedig már Flechsig ${ }^{3}$ ) kimutatta, hogy e nyaláb térfogata az ágyéki részben legalább $1 / 3$-szor, a nyakiban pedig mégegyszer akkora, mint a hátiban. A duzzadásokban tehát arányosan növekszik,

1) Dr. Ludwig Stieda: Studien über das centrale Nervensystem der Wirbelthiere. Zeitschrift für wissensch. Zoologie XX. 1870. 2\$8. 1.

2) Dr. Lenhossélk Mihály: A velöshüvelyek fejlődése az egér gerinczvelejében. Mathematikai és természettudományi Értesitö. VI. köt. 136. lap.

3) Dr. Paul Flechsig: Die Leitungsbahnen im Gehirn und Riickenmark des Menschen. Leipzig, 1875. 313. 1. 
a mi arra utal, hogy rövid, magában a gerinczvelöben eredö és végződő rostokból épül fel. Igaz, hogy újabban maga Flechsig*) is kijelenti, hogy a Burdach-féle nyalábok "oly rostokat is tartalmaznak, a melyek az agyvelöbe mennek fel", - de hozzá teszi, hogy "e rostok leginkább a felső végtag idegeivel függnek össze», vagyis e nyaki duzzadásban erednek. Flechsig felfogása tökéletesen megegyezik avval, a melyet fentebb - a Burdachféle nyaláb három zonájáról szólva - kifejtettem; én is kiemeltem ott, hogy a nyaki idegek gyökereinek egy része valószínüleg nem végződik in loco, hanem fel és talán lefelé is megy, felül a hátulsó nyalábok magvaiban, alúl a Clarke-féle oszlopokban érve véget.

Edinger czikkében fölemlíti és le is rajzolja egy 3 hetes macska gerinczvelejét. Észleleteim szerint a hátulsó gyökerek végzödése az elülsö szarvakban épen ez állaton látható legmeggyőzőbben s így egészen érthetetlen elöttem, hogy e végződés hogyan kerülhette el figyelmét.

\section{Összefoglalás.}

1. A mediális esoport az ember, macska, házi nyúl, tengeri malacz és egér gerinczvelejében nagyjában egyforma járású; az eltérések nem fontosak.

2. Útjának első szakaszában két részre oszlik : a) egyenes rostokra és b) hátulsó-nyaláb-rostokra. Amazok mindjárt átmennek a Rolando-féle állományon, utóbbiak a Burdach-féle nyaláboliba merúlnek, azokban részben rövidebb, részben terjedelmesebb darabon hosszában járnak s csak azután térnek be a hátulsó szarvakba.

3. A Burdach-féle nyalábok három részből állanak: a) a besugárzó rostok zonájából, b) elülső és c) hátulsó zonából. Az első a rövid járású, esakhamar a szürke állományba mélyedö gyökér-rostokat, a két utóbbi a hosszabbakat tartalmazza.

4. A Rolando-féle állomány elött a két csoport találkozik,

*) Dr. Paul Flechsig: Plan des menschlichen Gehirns. Leipzig, 1883. 21. lap. 
egy darabon tömött nyaláb képében előre megy, de csakhamar szétoszlik. Végzödése szerint megint két részre válik szét, a) a Clarke-féle oszlopokhoz, és b) az elülsö szarvakhoz menö rostokra.

5. Az elülső szarvakba lépő rostok végzödése kétféle : legnagyobb részök e szarvak rosthálózatába mélyed, kisebb részök a lateralis sejtesoporthoz követhetö.

6. A Clarke-féle oszlopokba menő rostok összefüggnek ez oszlopok sejtjeivel.

7. Az elülső eresztékhez e csoportból egy rost sem megy.

8. A hátulsó ereszték tartalmaz néhány, e csoportból eredő rostot.

\section{Középső csoport.}

E esoport rostjait, $36 \mathrm{~cm}$. h. magzaton találtam legelöbb velös állapotban; ez idötájban járásuk a legvilágosabban tanulmányozható. Vastagság tekintetében nem maradnak el a mediális csoport rostjai mögött. Legtöbbször vaskos nyaláb képében találkozunk velök, a mely a mediális csoporttól eltérve, elöre tart s egyenesen áthalad a Rolando-féle állományon, a közepe tájékán, a hátulsó gyökerek belépésével szemközt, s ez állomány halvány alapjáról élesen válik le.

E rostok fösajátsága abban áll, hogy a Rolando-féle állomány elé érve, homorúságában hirtelen hosszanti irányba hajolnak át s amaz erös nyalábokat képezik, a melyek Kölliker óta*) a "hátulsó szarvak hosszanti nyalábjai" néven ismeretesek. Ez áthajlás úgy fel- mint lefelé esik meg; hosszanti szeleteken - nem ugyan az ember, de a tengeri malacz gerinczvelején - e tényröl egész biztosan meggyőzödhettem.

E hosszanti nyalábok föcsomója a Rolando-féle állomány középső része előtt fekszik, de nem szorítkoznak e pontra, hanem beljebb is feltaláljuk öket, az állomány mediális fele elött, egész a Burdach-féle nyalábokig. Az ágyéki részen rendkívül erős fejlődést tüntetnek fel s belül egyenesen folytatódnak

*) Albert Kölliker: Handbuch der Gewebelehre des Menschen. 5. Aufl. Leipzig, 1867. 262. 1. 
a Burdach-féle nyalábokba. E tájékról vett szeleteken úgy mutatkozik, mintha a Burdach-féle nyalábok oldalt a hátulsó szarv s a Rolando·féle állomány belső fele közé széles nyújtványt küldenének, a melynek tömöttsége sokszor olyan, mint magoké a nyaláboké, máskor lazább elrendezödésủek. A középső csoport nyalábjai legtöbbször e nyújtvány legszélsö részébe bocsátkoznak, máskor egész terjedelmében lépnek hozzá; elöbbi esetben úgy aránylanak hozzá, mint a zászlóhoz a nyele. A háti részen e hosszanti nyalábok csak a Rolando-féle állomány közepe tájékán fekszenek, a nyakin ismét az elöbbi typus ölt kifejezést. A nyaki duzzadás legfelső szakaszában azonban nevezetes változással találkozunk : e nyalábok kivonúlnak a Rolandoféle állomány oldalsó fele elé, s immár nem a Burdach-féle, hanem az oldalsó nyalábokhoz szegödnek közvetetlenúl.

Majd minden szeleten észlelhetö néhány, e csoporthoz tartozó erős rost, a mely nem jár a többi módjára egyenesen, hanem a Rolando-féle állományt a külső oldala felöl ívalakban megkerüli, elülső széle elött befelé hajlik s így esatlakozik a hosszanti nyalábokhoz. Már e helyen megemlítettem azonban hogy egyesek e "körülhajló rostok» közűl nem mennek ez utóbbiakhoz, hanem az oldalsó nyalábokban vesznek el, vagy pedig egyenesen elöre tartva az elülsö szarvak felé veszik útjokat. Ez ívjárású rostok $36 \mathrm{~cm}$.-nyi magzatokon rendkívül határozottan tünnek elö, mivel az egész terület, a melyet befutnak : a széli zona meg az uldalsó pyramis-nyaláb, ez idötájban még tökéletesen velötlen. Ha nagyobb számmal vannak jelen, a hátulsó gyökerek kehelyszerű szétválása élénken tünik elö: befelé a mediális, egyenesen elöre a középső csoport elemei s kifelé e körülhajló rostok haladnak.

Már a hosszanti nyaláboknak közetlen odacsatlakozása a Burdach-féle nyalábokhoz, utal arra, hogy a mediális és középsó csoport rostjainak jelentősége közt valamely fontosabb eltérés nem áll fenn. Bizonyítja ezt azonban az az észlelet is, hogy igen gyakran a mediális csoport elemeiből néhányan kifelé hajolva a hosszanti nyalábokhoz szegödnek, viszont a középső csoportéi közúl egyesck elvonúlnak az utóbbiak mellett: a nélkül hogy vonatkozásuk lenne hozzájok s a mediális csoport mintájára az elülső szarvak felé tartanak; e csere egyes állatoknál még 
nagyobb arányban létesúl. További támasztéka ennek az is, hogy mint már fentebb elmondottam, a mediális és középső esoport közt compensatorius viszony áll fenn.

Nem egyszer látjuk, hogy a középső esoport rostjai, mielött még a Rolando-féle állomány elülső szélét elérték volna, magában az állományban hosszanti irányba csapnak át, sőt megeshetik ez mielőtt még abba beléptek volna, a "széli zona" területén. E nyalábokat már Krause ${ }^{1}$ ) leírja, megemlíti azokat Lissauer ${ }^{2}$ ) is, a ki kiemeli, hogy (igen gyakran, de nem állandóan szigetszerüen szétszórva, tömött, hosszanti nyalábok láthatók a kocsonyás állomány spongiosus zonájában, a melyek hol durva, hol pedig keverve finom és durva rostokból állanak".

Felnött ember gerinczveleje legtöbbször nem alkalmas a középső esoport vizsgálására : a mediális esoport külső rostjai ugyanis azt hosszanti nyalábjaival együtt csaknem egészen elfedik ; csak a fejlődéstan és összehasonlító anatómia vet nála e csoportra világot.

Mi a hosszanti nyalábok alkotó részeinek további sorsa?

$\mathrm{E}$ kérdés biztos megoldása a nehezebb feladatok közé tartozik. E rostok a hosszanti nyalábokról nem esoportosan, hanem fonalankint, egyenletesen szétosztva válnak le, s ezért egy-egy szeletre csak kevés jut belölök. Bár ez okból a kutatás itt nehéz téren mozog, mindazáltal arra a meggyözödésre juthattam, hogy e rostok javarészének ugyanaz a végzödése, mint a mediális esoport rostjaié, t. i. az elülső szarvakba mennek. Ilyen járású rostokkal minden szeleten találkozunk.

Gyakran észlelhetünk még olyanokat is, a melyek e hoszszanti nyalábokból nem elöre, hanem egyenesen kifelé tartanak, a Rolando-féle állomány elülső széle mentén s az oldalsó nyalábok legbelső részébe merúlnek. Itt valószínüleg hoszanti irányba térnek át, a "határréteg" nyalábjai közúl a durvábbakat képezve. E rostok már a $36 \mathrm{~cm}$.-nyi magzaton élesen elötünnek; leginkább a nyaki és ágyéki részen vannak kifejlődve, a háti darabon legtöbb szeleten hiányzanak. További sorsukat illetőleg lehet, hogy az oldalsó nyalábokban fölfelé haladnak,

1) Krause : i. m. 390. lap.

2) Lissauer: i. m. 394. lap. 
egész az agyvelöig. E nyalábokból azonban jelentékeny rostbesugárzás észlelhető az elülső szarvakba, valóbbszínü, hogy folytatásaik ezek között vannak.

Harmadik vonatkozása a középső csoportnak a hátulsó eresztékhez van. A commissura posterior az embernél aránylag gyenge fejlödésü, rostjai legnagyobb részét már $40 \mathrm{~cm}$. hosszú magzatokon velös állapotban találjuk. $\mathrm{E}$ korábban velösödö rostok valamennyien egyenes foly tatásai a hátulsó gyökereknek s két forrásból jönnek, t. i. a medialis és középső esoportból. E pontra nézve tehát ellenkezö eredményre jutottam, mint Bechterew*); szerinte a hátulsó gyökerek rostjai közül csak a lateralisok járulnának hozzá. Bechterew ez állítását amaz észleletére alapítja, hogy "magzatok gerinczvelejében a hátulsó ereszték egyetlenegy velös rostot sem tartalmaz, csak közetlenül a születés elött és újszülötteknél találunk ilyeneket benne». $\mathrm{Az}$ én észleleteim mást tanúsítanak. $36 \mathrm{~cm}$.-nyi magzatban igen világosan láthattam, hogy a Burdach-féle nyalábok besugárzó zonájából egyes erős rostok lépnek a szürke állományba, de benne nem haladnak mélyebbre, hanem mindvégig a hátulsó széléhez ragaszkodva, átmennek a másik oldalra s az ellenkezö oldal Burdach-féle nyalábjába merülnek. Ugyanez időben elölépett már néhány velös rost, a mely a hátulsó szarvak hosszanti nyalábjaiból leválva ferdén befelé és elöre tart s a Clarke-féle oszlopok mögött az elöbbeniekhez csatlakozik. Mind e rostok nyilván az ellenkezö oldalon is oda mennek, a honnan jöttek : a medialisok a Burdach-féle nyalábokba, a lateralisak a hosszantiakba. További járásuk azután ugyanaz lehet, mint ama rostoké, a melyekhez szegödtek.

Kifejlödött ember gerinczvelejét vizsgálva, a hátulsó ereszték rostjait csakugyan számosabbaknak találjuk, mint az újszülött gyermeknél. E később hozzájárúlt, jobbadán finom rostok eredésére nézve azt tartom legvalóbbszínünek, hogy a Rolandoféle állomány elött fekvö idegsejtekböl erednek s bennök végződnek is a tulsó oldalon.

Macskában a középső csoport még gyengébb a medialishoz képest, mint az emberben. Újszülött és 3 napos macska gerincz-

*) Bechterew : i. m. 135. 1. 
velejében e csoport még esaknem velötlen, a 7-ik napon azonban már derekasabban velös állapotban találjuk. Nevezetes különbség az emberrel szemben az, hogy az e esoporthoz tartozó hosszanti nyalábok a Rolando-féle állománynak nem belsö, hanem külső fele elött fekszenek s az oldalsó nyalábokhoz csatlakoznak. Az e hosszanti nyaláboktól eredö, elöre tartó rostok igen szépen láthatók; járásuk olyan, hogy eleinte kissé medialis irányban haladnak, mintha az elülsö eresztékbe akarnának lépni, de utóbb kifelé hajolnak s az elülsö szarvakba térnek be. A hátulsó eresztékben néhány velös rost látható már.

Újszülött és 5 napos házinyúlon a középső csoport elemei közül csak néhány velös még. A typus itt ugyanaz, mint a macskánál : a hosszanti nyalábok a Rolando-féle állomány lateralis része előtt sorakoznak. A commissura posterior néhány velős rostot tartalmaz, a melyek azonban valamenyien az ez időtájban már jóformán egészen velös medialis esoport egyenes folytatásai.

A tengeri malacz gerinczvelejében a hátulsó gyökerek középsö csoportja valamennyi állat közúl legjobban kutatható. Egy az, hogy e csoport itt igen erösen van kifejlodve, jó részét, körülbelül felét teszi a hátulsó gyökereknek, másrészröl pedig megkönnyíti a vizsgálatot az a körülmény, hogy e csoport, a mely a kifejlödött ember gerinczvelejében a medialis esoporttól jórészt elfedetik, avval jóformán egygyé olvad össze - itt felszabadúl, töle oldalvást, külön fekszik.

A tengeri malacz gerinczvelejét vizsgálva azt látjuk, hogy a hátulsó gyökerek rostjai részben befelé kanyarodnak a Burdach-féle nyalábokba, részben átmennek a Rolando-féle állományon, annak egész medialis felét elfoglalva. Ez utóbbi rostok ez állomány elülső szélénél hirtelen igen élesen két széthajló esoportra válnak szét : medialisabb nyalábjaik tovább haladnak elöre - ezek a medialis csoport "egyenes rostjai", a melyekkel föntebb már részletesen foglalkoztunk, - lateralis nyalábjaik azonban az állomány elött hirtelen kifelé fordúlva, elülső széle mentén harántosan kifelé tartanak. Mindmegannyian erös, vastag rostok, ezek alkotják a középsö csoportot.

Majdnem minden szeleten észlelhetjük, hogy e kifelé hajló rostokhoz a medialis csoport alkotó részei közül is hozzácsatla- 
kozik néhány, sót láttam olykor azt is, hogy a Burdach-féle nyalábokból a szürke állományba nyomúló rostok valamennyien kifelé vették útjokat, a középsö esoport módjára.

Hogy leírhassam e rostok további sorsát, szükségesnek tartom, hogy a hátulsó szarvak alkotásáról egyet-mást elmondjak.

E szarvak, a mint ismeretes, két eltérö részböl állanak : a tulajdonképeni hátulsó szarvból s az ezt hátulról félholdalakban beborító Rolando-féle állományból. Ez utóbbi nem tartalmaz idegsejteket, hanem csupa részben elszarúsodott ektodema sejtböl van összerakva, a melyek sagittalis sorokba rendezkednek, s a köztük lévö bö alap állomány sötét-sárga alapján halcányabb, gyakran festetlen voltuk révén tünnek elö. Ez állomány elöre fordúlt homorúságában, a Weigert eljárásával festett készítményeken, rendkívül finom rostok gazdag fonata s apróbb, s helyenkint nagyobb, többsarkú idegsejtek ötlenek szemünkbe, E fonat rostjai nagyobbára hosszában futnak, a miröl hosszanti szeleten könnyen meggyözödhetünk; harántszeleten ezért leginkább rostpontokkal találkozunk e téren. E zona közönségesen substantia spongiosa néven ismeretes, legszélesebb az a homorúság külső, mélyebb zugában, befelé mindinkább megkeskenyszik.

Elötte következik már most a tulajdonképeni hátulsó szarv. Ez a tengeri malacznál két részre oszlik. Medialis harmada a hátulsó gyökerek medialis esoporțának átlépésére szolgál s hosszanti rostokat nem tartalmaz, a két oldalsónak az a sajátsága, hogy számos, hosszában futó nyalábot találunk benne, meglehetős symmetriás elrendeződésben. Ezek oldalt határ nélkül esatlakoznak az oldalsó nyalábokhoz, a melyeknek mintegy fellazúlt folytatásai. Területök egészben véve háromszögletú, az oldalsó nyalábokhoz szegödö alappal s befelé, a hátulsó szarvba nyomuló, s medialis harmadáig érö csúcsesal. A küljebb fekvő nyalábok vaskosabbak, a belsők s kivált a hátrább esők finomabbak, szétszórtabbak.

A hátulsó gyökerek középső esoportjának e nyalábok közúl csak a hátulsókhoz van vonatkozása; e nyalábok tehát nem egyforma jelentőségúek, az elülsők egyszerúen az oldalsó nyalábokhoz tartoznak, a hátulsók a középsö csoport egyenes foly- 
tatásai s a "hátulsó szarvak hosszanti nyalábjai" -val azonosak. Különbség tehát az emberhez képest annyiban van, hogy ez utóbbiak itt egyrészt nagyobb számmal vannak, másrészt nem fekszenek a Rolando-féle állomány belsö, hanem inkább külsö fele elött. A középsö esoport rostjai a spongiosus állomány rosthálózatába nem mennek át.

Ama, szintén e esoporthoz tartozó, a Rolando-féle állományt kívülröl ívalakban megkerülö rostok, a melyekről az embernél szóltunk, itt is feltalálhatók, erős fejlödésben.

Milyen a hosszanti nyalábok rostjainak további járása? Az eredmény itt sem egyéb, mint az, a mit az embernél állapíthattunk meg. A szeletek figyelmes átvizsgálásánál azt látjuk, hogy közülök némelyek egyenesen elöre tartanak az elülsö szarvak felé, mások tovább folytatják harántos útjokat az oldalsó nyalábok irányában, a melyekben azután elvesznek; e nyaláboknak harmadik, legbiztosabban megállapítható összeköttetésök a hátulsó eresztékkel van.

A tengeri malacz hátulsó eresztéke rendkívül erős, a mi összefügg a középső csoport s hosszanti nyalábjai hatalmas fejlettségével. Hogy mindazáltal igen sok szeleten nyomát sem találjuk, annak a magyarázatát a hosszanti szeletek adják meg; ezeken ugyanis arról bizonyosodunk meg, hogy ez ereszték nem formál folytonos, egyenletes réteget a gerinczvelö hosszában; hanem egymástól egyforma távolságra levő tömött nyalábokba sorakozik; ha a hosszanti szelet sagittalis irányú volt s a középvonalhoz közel vezettetett, az ereszték harántszelete a szürke állomány hátulsó részében, egymás felett egyenlö közökben fekvő gömbölyü pettyek képében mutatkozik. Ha a harántszelet megfelelö pontot talált, úgy a hátulsó ereszték ívalakú, egész terjedelmében vaskos nyalábként ötlik szemünkbe; az ív helyett talán találóbb volna az ellapúlt patkó hasonlata, a mennyiben az ív két szára nem hajlott, hanem legtöbbször egyenes, sőt gyakran épen kissé befelé, ellenkezö irányban concav. A tömött nyaláb a hosszanti nyalábok leghátulsóbbjaiból s részben az ideghálózatos zonából ered összehajló rostokkal, ferdén befelé és elöre tart, a Clarke-féle oszlopok mögött elhaladva, az ellenkező oldalra lép s ott ugyanazon a ponton végzödik; útközben fölvesz néhány rostot a medialis esoportból is, a 
melylyel keresztezödik. Helyzete annyiban eltérö az embernél észlelhetötöl, hogy nem fut szigorúan a szürke állomány hátulsó széle mentén, hanem valamivel elöbb; ez annak a következménye, hogy a középső csoport hosszanti nyalábjai, a melyekben ez ereszték főkép gyökeredzik, lateralisabb fekvésűek mint amannál. Megesik az is, hogy egyik vagy másik oldalon nem vonúl el a Clarke-féle oszlop mögött, hanem rajta átfuródik. Belső vonatkozása ez oszlopokhoz egyébiránt úgy látszik nines.

Igen sok szeleten észleljük, hogy azon a ponton, a hol áthalad a középvonalon, egyes rostok válnak le róla, a melyek egyenesen hátrafelé húzódva, a Goll-féle nyalábokban érnek véget.

Mind ezekböl tehát az tünik ki, hogy a hátulsó ereszték legnagyobbrészt a hátulsó gyökerek egyenes folytatásából áll: rostjait leginkább a középső, kisebb részben a medialis esoportból nyeri. Kétségtelen azonban, hogy van alkotó részei között számos, a mely nem ebbe a rovatba tartozik. Utal erre már eredésének a módja is: az imént láttuk, hogy, rostjainak egy része a hosszanti nyalábok mögött, a hálózatos zonában gyökeredzik; e - jobbadán finom - rostokat tehát más forrásból kell levezetnünk. Legvalóbbszínű az a magyarázat, hogy ezek a Rolando-féle állomány homorúságában levő idegsejtek nyújtványai.

A mi a commissura rostjainak végződését illeti, úgy látszik, valamennyi az ellenkező oldalon is oda megy, a honnan jött : a medialis esoportból eredők a Burdach-féle nyalábokhoz, a középsöböl származók a hosszanti nyalábokhoz szegődnek, s e nyalábok rostjainak további sorsában részesúlnek; a sejtekböl jövők a tulsó oldal hasonló elemeivel kapcsolatosak.

A hátulsó eresztéken kivül találunk a tengeri malacznál még egyéb, a hátulsó szarvak két felének összekötésére szolgáló rostokat is. Látunk ilyeneket kivált közvetetlen a középponti csatorna mögött ; finom ívalakú, elöfelé homorú járású rostok ezek.

A középsö csoport az egérben nagy analógiát tüntet fel a tengeri malacz idevágó viszonyaival. A különbség az, hogy e csoport itt gyengébb fejlődésú, mint amannál.

E esoport rostjai itt néhány erős nyalábba rendezkedve, a Rolando-féle állományon a belső és középsö harmada közti 
határon nyomúlnak át, elülső szélénél elválnak a medialis csoport egyenes rostjaitól s ívalakúlag kifelé hajolnak. A Rolandoféle állomány homorúságát itt is finom ideghálózat foglalja el, a mely itt azonban feltünően szegényes, kevés rostú. Ez elött feltaláljuk az ismert, szétszórtan fekvö hosszanti nyalábokat, a melyek oldalt az oldalsó nyalábokkal folynak össze. E rostnyalábok közúl a hátulsók lazább szövetủek, ritkábbak; ezek azok, a melyekbe a középső csoport kifelé húzódó rostjai áthajolnak.

E nyalábok rostjainak további járását a következó észleletek világítják meg. Valamennyi hosszanti nyalábból jelentékeny sugárzást látunk az elülsö szarvak felé, végzỏdésök tehát jórészt ezekben keresendő; egyes rostjaik azonban az oldalsó nyalábok felé is tartanak, a melyek alkotórészei közé belevegyúlnek ; észlelünk ugyanide haladó rostokat, a melyek azonban direct a középső esoportból jönnek, a nélkül hogy hosszanti irányba tértek volna át.

Bizonyos, hogy a hosszanti nyalábok elemeik jó részét a hátulsó eresztékbe küldik. Ez az egérben gyengébb fejlődésú, mint a tengeri malaczban, de erösebb, mint az emberben. Különös sajátsága itt az, hogy két különálló részre válik szét élesen: elülsőre meg hátulsóra. E felosztás első nyomai már a tengeri malaczon is megjelennek.

Az elülső része gyengébb a hátulsónál; csak elvétve leljük összefüggő nyalábként a szeleten, legtöbbször csak töredékeivel taláikozunk. A hátulsó szarvak hosszanti nyalábjaiból ered, s ívalakban elöre és befelé halad. A hátulsó résztỏl a gerinczvelö egyes pontjai szerint különböző szélességủ köz választja el. Legszélesebb e köz a Clarke-féle oszlopok tájékán; ez oszlopok ugyanis a két rész között fekszenek, az elülső rész elötte fut el. A hol a középvonalon átlép, szintén észlelünk belőle lekanyarodó, egyenesen hátrafelé, a Goll-féle nyalábokba tartó rostokat; ezek persze útjokban elsőben a szürke állományon kell, hogy átnyomúljanak s csak azután lépnek a septum posteriusba. E rész rostjainak eredése tehát a középső csoportban állapítható meg : elemei egyenes folytatásai a hátulsó gyökerek alkotó részeinek.

A hátulsó rész a szürke állomány hátulsó, patkó-alakú szé- 
léhez ragaszkodik. Rostjai részben a Burdach-féle nyalábokból szedődnek össze, tehát a medialis esoportból jönnek, részben a Rolando-féle állomány elülső szélénél, a belsö fele elött erednek. Ez utóbbi finom rostok származásának két lehetöségével kell számolnunk; vagy folytatásai a Rolando-féle állomány belső részén átnyomuló, a medialis csoporthoz tartozó rostoknak, vagy nyújtványai az ez állomány elött szétszôrtan fekvő apró idegsejteknek. Hogy itt csakugyan vannak ily sejtek, azt karminfestéssel biztosra kideríthetjük. Csoportjok különösen a Rolando-féle állomány legmedialisabb része elött halmozódik fel. A commissura posterior e részéböl szintén lefüződik a középvonalon egy pár rost, a mely a septum posterius útján hátra felé halad.

A velöképződés idejére nézve a középsర̋ csoportban a következőket találtam. Már 9 napos egérben lát az ember egynéhány, e esoporthoz tartozó, a Rolando-féle állomány elött kifelé hajló rostot, de számuk igen esekély; a hozzájok tartozó hosszanti nyalábok még esaknem egészen velötlenek. A 14 napos egér gerinczvelejében a középsö csoport félig velös, valamint a hosszanti nyalábok is; a hátulsó eresztéknek mind a két része szintén számos velös rostot tartalmaz, de még korántsem oly erős, mint kifejlödött állapotban. A 18-ik napon a hátulsó gyökerek teljesen velösek.

Jegyzet. Minthogy e esoport viszonyai fökép a fejlödéstan és összehasonlító anatomia révén állapíthatók meg, azok a szerzők, a kik a hátulsó gyökerek járását esak kifejlödött emberek gerinczvelein vizsgálták - a hol az, mint említettem, nem válik ki elég világosan - e csoportról vagy mit se szólnak, vagy legalább is nem emelik azt ki kellökép.

Leginkább egyezik az én észleleteimmel a Krause leírása, $\measuredangle$ is három esoportot ismer, $\mathrm{s}$ a mit a középsőröl mond, azt csaknem teljesen aláírhatom. E esoport rostjai szerinte áthaladnak a Rolando-féle állományon, s elötte részben fel-, kisebb részben lefelé hajolva, a hátulsó szarvak hosszanti nyalábjaiba kanyarodnak át. Ez utóbbiak hol a Rolando-féle állomány elött haladnak, hol meg inkább lateralis fekvésüek; a sacralis részben elszigetelt esoportot alkotnak.

Schwalbe középső esoportot nem különböztet meg, de kiemeli, hogy az 0 lateralis esoportjának, vagy is az összes, a Rolando-féle állományon átnyomúló rostoknak legnagyobb 
része hosszanti irányba fordúl (hátulsó szarvak hosszanti nyalábjai), de utóbb ismét vízszintes irányba tér át.

Bechterew a mi középső csoportunkat a medialishoz számítja, a melynek a Rolando-féle állományon átnyomúló rostjairól fölemlíti, hogy részben hosszanti nyalábokba sorakoznak, részben direct elöre haladnak a szürke állományban. A medialis esoportból (tehát a mi medialis középsö csoportunkból) rostokat a hátulsó ereszték felé nem követhetett; ez állítását már föntebb igyekeztem megezáfolni.

Obersteiner felosztása megegyezik a Schwalbe-éval. A lateralis csoportban mind azokat a rostokat foglalja össze, a melyek a Rolando-féle állományon lépnek át, tehát a mi középső csoportunkat, meg a medialis esoport "egyenes rostjai-t». Elemei részben hosszanti irányba kanyarodnak át, részben "talán" az ez állomány elött fekvő idegsejtekben érnek véget. Észleleteimtöl eltér az az állítása, hogy a hátulsó ereszték rostjai volószínüen nem egyenes folytatásai a hátulsó gyökereknek.

Lissauer leírása a középsö esoportra nézve a Schwalbeéhoz ragaszkodik.

\section{Összefoglalás.}

1. A középső esoport legerösebb fejlettségü a tengeri malaczban, gyengébb az egérben, házi nyúlban, macskában, legsilányabb az emberben.

2. Erös idegrostokból áll, a melyek valamivel később kezdenek velösödni, mint a medialis esoport rostjai.

3. A Rolando-féle állomány hátulsó szélénél két irányba hajlik szét: a) javarésze egvenesen áthalad a Rolando-féle állományon, erös nyalábok képében; $b$ ) néhány rostja kifelé kanyarodik, s ez állományt a külső oldala felöl ívalakban megkerüli.

4. Rostjai a Rolando-féle állomány elött valamennyien hosszanti irányba térnek át s a "hátulsó szarvak hosszanti nyalábjai-t» (Kölliker) alkotják. Ez áthajlás úgy föl-, mint lefelé észlelhetö.

5. E hosszanti nyalábok az embernél a Rolando-féle állomány medialis fele elött fekszenek, jórészt elfedetve a medialis esoportnak a hátulsó szarvakba behajló rostjaitól; belül köz- 
vetetlenúl a Burdach-féle nyalábokhoz csatlakoznak. Állatokon ellenkezőleg az állomány lateralis fele (macska, házi nyúl) vagy ${ }^{2 / 3-a ~(t e n g e r i ~ m a l a c z, ~ e g e ́ r) ~ e l o t t t ~ t a l a ́ l j u k ~ s ~ o l d a l t ~ e ́ l e s ~ h a t a ́ r ~}$ nélkül folynak egybe az oldalsó nyalábokkal.

6. Elemeik ismét vízszintes irányt véve háromféle úton haladnak tovább : a) egy részök elöre megy az elülsö szarvakhoz, b) néhányan az oldalsó nyalábok legmedialisabb részébe vegyúlnek; c) mások a hátulsó eresztékbe követhetők.

7. A hátulsó ereszték legerösebb a tengeri malaczban, az emberen aránylag igen gyenge. Az egérben két különálló részre válik szét : elülsőre meg hátulsóra.

8. Alkotórészeit több forrásból nyeri : a) legnagyobb részök a hátulsó gyökerek egyenes folytatása. E rostok részben a medialis, részben a középsỏ esoportból jönnek s már 36 cm.-nyi emberi magzatoknál velösek; $b$ ) késöbb, az emberben esak a születés után velösödnek ama finomabb rostjai, melyek a Rolando-féle állomány elött fekvő idegsejteket kötik össze egymással a két oldalon.

\section{Lateralis csoport.}

E csoport fölfedezésének s kórtudományi jelentösége fölismerésének érdeme Lissauer nevéhez füzödik. Hogy a kutatók figyelmét oly soká elkerülhette, annak okát rostjainak nagy finomságában s ehhez képest az elöbbeni festési módszerek fogyatkozásaiban kereshetjük. Oly vékonyak ezek, hogy karminfestés mellett - a mely még néhány évvel ezelött egyedül volt használatos e czélra - nem emelkednek ki eléggé; feltüntetésökre csak azok a festések alkalmasok, a melyek a legfinomabb idegrostokat sem hagyják festetlenúl. Ilyen a Weigert-féle hæmatoxylin-módszer; ennek a segélyével fedezte fel e csoportot Lissauer.

Ha elemeit e festés útján elötüntethetjük is, kapcsolataik, végződésök teljes kiderítése eddigelé még nem sikerült. Az az alább közlendö felfogás, a melyet járásukról alkottam magamnak, se tarthat egyébre számot, mint hogy felvételnek tartassék. Bizonyságot e téren további tapasztalatokból, a meglevőknél 
még tökéletesebb módszerektöl, a kórtudomány s a physiologiai kísérletek eredményeitöl kell várnunk.

E rostok finomságának a következménye, hogy a velösödés bennök jóval később köszönt be, mint a hátulsó gyökerek másik két esoportjában. Még $36 \mathrm{~cm}$. h. emberi magzatban hiába keressük e rostokat a szeleten. A Burdach-féle nyalábok velös területe kívül, a Rolando-féle állomány medialis része mögött hírtelen, éles vonallal megszünik. Ez állomány s a peripheria között szegélyszerú, tökéletesen velötlen terület húzódik el, mely oldalt minden határ nélkül megy át a szintén velötlen oldalsó pyramis-nyalábba. A hátulsó gyökerek erős, velös nyalábjai e szegélyszerú zona medialis részén lépnek be a gerinczvelöbe, $\mathrm{s}$ a sárgás alapról élénken emelkednek ki. Az oldalsó nyalábok legbelsö részén, az u. n. határrétegben ez idötájban még jóval kevesebb a velös elem, mint később : alig lelünk egy pár velös nyalábot benne.

45 cm.-nyi magzat gerinezvelején a szegélyszerú szélsö területen elszórtan finomidegrostok harántszeletei kötik le figyelmünket. A határrétegben is haladt a velősödés. A Rolando-féle állomány homorúságában egyenetlenűl szétszórva kevés rost-töredék jelenik meg.

Már a velőfejlődés eme megegyező, lépést tartó előhaladása utal tehát arra, a mit - mint alább megmutatjuk, - a direct észlelet is bizonyít, hogy t. i. rendszerbeli összefüggés áll fenn a "széli zona", a "spongiosus állomány" alkotó részei s a határréteg egyes elemei között.

Újszülött gyermeken jóval haladottabb viszonyokkal találkozunk. A hátulsó gyökerek medialis és középső esoportja ez időben már elérte fejlődése teljét, a lateralis csoport sem áll a befejezéstől távol, bár még mindig áttekinthetőbb, mint a kifejlödött ember gerinczvelejében.

E csoport járásának sarkalatos pontját a Lissauertől "széli zoná) -nak nevezett területhez való viszonya képezi s így elsöben is erre kell ügyet vetnünk.

A hátulsó szarvak, vagy pontosabban a Rolando-féle állomány az emberben a gerinczvelö egy pontján sem ér a peripheriáig, (egyes állatokban, tengeri malaczban, egérben, jóformán egészen eléri azt). Az a réteg, a mely töle elválasztja, külön- 
bözó alakú a gerinczvelö egyes magasságaiban; idoma a hátulsó szarvak alkotásától függ.

$\mathrm{Az}$ ágyéki részben e szarvak duzzadtak, gömbölyüek. Hátulsó szélök medialis harmada még a Burdach-féle nyalábba nyomúl, lateralis ${ }^{2} / 3$-a párirányosan jár a peripheriával s így köztök egy, fehér állományból álló terület marad, mely a hátulsó szarvat elnyúlt, de keskeny rétegben borítja: ez a "széli zona".

A háti darabon a megkeskenyedett hátulsó szarv kissé elhúzódik a kerülettỏl. Ennek az a következménye, hogy a zona jobbról-balra valamivel keskenyebb, elölről hátra ellenkezöleg szélesebb lett, azonban átméröje még mindig nagyobb az elöbbi irányban, mint az utóbbiban.

Idomának ilyen értelemben való változása folytatódik és fokozódik fel egész a nyaki szakaszra, a hol tetópontját éri el. Itt ugyanis a hátulsó szarv még erösebben összeszorúlt s egyúttal jobban eltávolodott a gerinczvelö szélétöl. Ennek folytán a széli zona jelentékenyen megváltozott alakban lép elö. Immár nem haránt tengelye a hosszabbik, hanem a sagittalis; elölröl-hátra elnyúlt, jobbról-balra összelapúlt alakúvá lett.

Befelé a gerinczvelö minden magasságában a Burdach-féle nyalábbal határos, kifelé az ágyéki meg háti részen csak az oldalsó pyramis-nyalábbal, a nyakin félig evvel, félig az oldalsó kisagyvelöi pályával. Az oldalsó nyalábok határrétegével sehol sincs közvetetlen érintkezése.

A zona a felnött ember gerinczvelején kifelé nem igen éles határú, s látszólag egybefolyik az oldalsó nyalábok alkotórészeivel. Újszülöttek gerinczvelejét, vagy tabeses gerinczvelöket vizsgálva azonban e zonának e nyaláboktól raló független, önálló voltáról biztosan meggyöződhetünk; tabesnél t. i. Lissauer észleletei szerint önállóan betegszik meg. Befelé a határ mindig igen éles, a Burdach-féle nyalábok erös rostesoportjai mindenkor egyenes, határozott vonal útján válnak el e zona finom rostrétegétől.

A hátulsó gyökerek a széli zona medialis határa közelében, de annál mégis kissé küljebb nyomúlnak be a gerinczvelbbe; ennek következtében a zonán ferdén át kell, hogy lépjenek, leválasztva belöle a medialis oldal felöl egy kis darabot.

$\mathrm{E}$ terület rostjainak jelentőségére világot vet az az észlelet, 
hogy a duzzadásokban arányosan növekszik, közöttük arányosan fogy, a miböl azt a biztos következtetést vonhatjuk le, hogy egyedúl vagy legalább is nagyrészt rövid, azaz a gerinczvelöben magában eredö és végzödỏ rostokból épül fel; ha hosszúkat tartalmazna, harántszeletének nyilván alulról fölfelé növekedni kellene.

A Lissaner-féle zona belső alkotását kutatva, elöször is feltünik hogy a támasztó szövetnek e zona alkotásában nagy része van. Régibb szerzők egyedúl kötöszövetböl állónak tartották; csak Henle ${ }^{1}$ ) és Fromman $^{2}$ ) vette észre az alapállományba ágyazott finom idegrostokat. $\mathrm{E}$ támasztó szövet két alakban jelentkezik : először egyenletesen szétosztva e zona egész területén, mint valódi "alapállomány", azután erös, durva sövények képében, a melyek a gerinczvelö felszínét befedö s e helyen erösebb gliaburkolattól indúlva ki, a Rolando-féle állomány felé tartanak, a melynek hátulsó részével összefüggnek. —. E sövények iránya igen jellemző és állandóan ugyanaz: ferdén elöre s kissé kifelé haladnak, a hátulsó gyökerek belépése helye felöl a Rolando-féle állomány külsö része felé. Ez irány annyiban érdemli meg figyelmünket, mivel fentebb, a mikor a Burdachféle nyalábok középső zonájáról szóltam, valószínünek jelentettem ki, hogy a gliasövény irányára a hézagaikban futó idegrostok járási befolyással van, s így viszont e sövények iránya világot vethet a közöttük levő nyalábok sorsára, viszonyaira.

E sövények hézagjaiba számos, hosszában futó rost helyezkedik. Ismertető jelök elsőben is igen finom voltukban, azután abban áll, hogy sehol se tömörülnek erösebb nyalábokká, hanem egyenletesen szétszórva haladnak. Finomságuk és laza elrendezödésök következménye, hogy gyengébb nagyítással nézve a Weigert-féle szeleteket, e zona nem emelkedik ki a fehér állomány jellegzetes sötét színezetében, hanem halványabb, a fehér s szürke állomány közti átmenet színében mutatkozik. E leírás azonban csak a legközönségesebb lelet viszonyait

$\left.{ }^{1}\right)$ Dr. Jacob Henle: Handbuch der Nervenlehre des Menschen. Braunschweig, 1871. 51. lap.

$\left.{ }^{2}\right)$ Dr. Carl Fromman: Untersuchungen über die normale und pathologische Anatomie des Rückenmarks. Jena, 1864. 47. lap. 
tünteti elö; észlelhetö olykor az is, hogy rostjainak tömöttsége valamivel erősebb belül, a belépő gyökerek tájékán, s kifelé mindinkább ellazúl. Szembeötlik néha egy-egy erösebb rostokból álló vaskosabb nyaláb is, a mely e terület finom alkotó részei közé ágyazódik. E nyalábokat, úgy látszik, már Lissauer is észlelte, a mennyiben értekezésében fölemliti, *) hogy "a jellemzö finom rostokon kívül egyes durvábbak is fordúlnak elö a széli zonában". Azok után, a miket feljebb a hátulsó gyökerek középső csoportjáról elmondottam, ez erösebb nyalábok jelentése érthetö: lehetnek ezek a csoport kifelé hajló rostjainak töredékei, vagy tartozhatnak annak egyenes rostjai közé, a melyekről feljebb megemlítettem, hogy olykor már a Rolando-féle állomány mögött, a széli zona területén hajlanak hosszanti nyalábokba át.

Mily forrásból nyeri alkotó részeit a széli zona? Lissauer érdeme, hogy megmutatta-e zona odatartozását a hátulsó gyökerekhez. Ez összefüggés kétségtelen; meggyözödhetünk erröl minden szeleten. Míndegyiken észlelhetni ugyanis finom rostokat, a melyek a hátulsó gyökerek oldalsó széléröl leválva kifelé kanyarodnak s e zona területén vesznek el ; ezek teszik a hátulsó gyökerek lateralis csoportját. Különösen feltünő egy kis, tömöttebb nyaláb, a mely közvetetlenúl a gerinczvelö peripheriáján, jóformán még a széli zonát borító glia-materben fut egy darabig kifelé, azután behajolva e zonába, finom rostjai között tünik el. E nyaláb persze csak a zona oldalsó részét táplálhatja; a többi részéhez menök a hátulsó gyökerek elülsöbb pontjairól, a belépésök helye s a Rolando-féle állomány közti darabjokról hajolnak le; eme, rövid darabon követhetö rostok járása mindig párirányos azután a glia-sövények irányával.

Ki kell azonban emelnem, hogy a lateralis csoport sok oly rostot foglal magában, a melyek nem járúlnak a Lissauer-féle zona képezéséhez, hanem a nélkül, hogy hosszanti irányba térnének át, a Rolando-féle állomány oldalsó részén át egyenesen elöre tartanak. A viszony tehát ugyanaz, mint a medialis és középsö csoportban: mind a kettö részben mindjárt vízszintesen to-

*) Lissauer: i. m. 380. lap. 
vább haladó, részben elöbb egy darabig hosszában futó rostokból áll.

Hogy vajjon valamennyi, a széli zonát alkotó rost a hátulsó gyökerekböl ered-e, az felette valószínü ugyan, de e kérdésre oly határozottan igent mondani, a mint azt Lissauer teszi, még se mernék. Vannak e tájékon ugyanis idegsejtek, a melyek kapcsolata e csoport elemeivel nem rekesztheto ki.

Felnött emberek gerinczvelejét nézve ugyanis erősebb nagyítással, a Rolando-féle állomány bátulsó részén érdekes megfigyeléseket tehetünk. A tulajdonképeni Rolando-féle formatio - szövettani értelemben, - voltakép nem terjed egészen a Lissauer-féle zonáig; a hátulsó szarv leghátulsó részét egy keskeny, a formatio Rolandicát hátulról félholdalakban, szegélyszerüen körülvęő terület teszi, a mely belsö alkotására nézve eltér e formatiótól, s inkább a szürke állomány egyéb részeivel azonos. $\mathrm{E}$ terület idegnemü alkotó részeket is tartalmaz, még pedig háromfélét: 1. néhány, a hátulsó gyökerekből jövö, ívalakúlag kifelé hajló, rendkívül vékony idegrostot, 2. néhány orsó-alakú, a Rolando-féle állomány szélével párirányosan fekvő idegsejtet, 3. igen szegényes, alig fölismerhetö ideghálózatot, mely nyilván e sejtek nyújtványaiból áll elö, azonban esak igen szorgos megfigyelésre tünik szembe. E hálózatnak újszülött gyermekben nyomát se látjuk : csak késöbb lép elö.

Nem lehetetlen, hogy a Lissauer-féle zona néhány alkotó része e sejtekből ered, a rosthálózat útján. Egy másik lehetöség abban kínálkozik, hogy egyes olyan rostok, a melyek a hátulsó gyökerek lateralis esoportjából jönnek s a széli zonában egy ideig hosszában jártak, e sejtekben érnek véget; e föltevést annál szívesebben fogadhatjuk el, mivel a lateralis csoport többi rostjaira nézve is hasonló, a Rolando-féle állomány homorúságában fekvő idegsejtekben való végződés bír legnagyobb valószínüséggel; e tekintetben tehát megegyezés lenne közöttük. Biztos feleletet persze itt nem adhatunk; ez összefüggés ellen esak egy szól, hogy t. i. e sejtek helyzete e végződésre nem alkalmas, mivel a peripheriával párirányosan, s így a széli zona elemeire derékszögben feküsznek.

De ha e végződés fölvétele a valóságnak meg is felelne, evvel bizonyára a széli zonát alkotó rostok egy részének a sorsa volna 
csak megfejtve. E sejtek száma sokkal kisebb, mintsem hogy e zona valamennyi elemei bennök végzödhetnének. Legnagyobb részök nyilván másfelé veszi útját; e mellett szól a direct észlelés is. $\mathrm{E}$ zona területéröl ugyanis minden szeleten számos, rendkívül finom rost válik le, a melyek áthúzódnak a Rolando-féle állomány lateralis részén, $\mathrm{s}$ az ennek vájúlatában fekvő ideghálózatba merülnek be. E finom rostok a középsö csoport durva nyalábjaival sehogy se téveszthetök össze, mível azoktól oldalvást fekszenek s nem esoportosúlnak soha tömött nyalábbá, hanem szétszórva, fonalankint haladnak elöre, párirányosan ez állomány hosszanti sorokba rendezkedő sejtjeivel. Legtöbbnyire csak töredékeikkel találkozunk, egész járásában ritkán jelenik meg egy-egy rost a szeleten. Legnagyobb mennyiségben a Rolando-féle állomány legkülső részén, az oldalsó széle közelében észlelhetők; e helyen mindig kissé ívszerü a járásuk. Számosan közúlök nem a széli zonából erednek, hanem magáról a hátulsó gyökérrobl válnak le, e rostokat mindazáltal a lateralis esoporthoz számítjuk, a melynek föismertetö jele nem a Lissauer-féle zonához való hozzájárulásában, hanem rostjai finomságában és járása viszonyaiban áll. Nagy számban találkozunk olyan rostokkal is, melyek nem lépnek át a Rolando-féle állományon, hanem ívszertien megkerülik oldalsó szélét, épúgy, mint a középső csoport külső ívjárású rostjai, a melyektől azonban vékony voltukra tekintettel biztosan megkülönböztethetök.

A Rolando-féle állomány homorúságában - épúgy, mint azt fentebb a tengeri malacznál tüzetesen leirtuk - egy finom rostú, gazdag ideghálózat terúl el, a melynek hézagjaiban számos apró, de néha egy-egy feltünö nagy idegsejt is fekszik. Legszebben tünnek elö e sejtek 30-32 em.-nyi magzatokban, a melyeknél gyakran sok myeloid anyaggal vannak megrakva. A hálózat, bár egészben igen szabálytalan szövetú, inkább hoszszanti irányban terjed el; hosszanti szeleteken reczeszerü al. kotása világosabban nyilvánúl. E hálózat észlelhető már az újszülöttọn is, de ez időben még korántsem oly szövevényes, mint később ; rostjainak jó része csak utóbb velösödik. E hálózatról nagy valószinúséggel állíthatjuk, hogy az itt fekvő idegsejtek nyújtványainak eloszlásábólés fonattá kapesolódásábóláll elö. 
Valamennyi a Rolando-féle állomány oldalsó részén átlépő, vagy a külsö oldalán elöre kanyarodó rost e hálózatos rétegbe, e substantia spongiosába merül : itt a végzödésök helye. S ha még végül hozzáteszszül, hogy valószinúleg e rosthálózat útján e sejtekkel kapcsolatosak, úgy mindent elmondottunk, a mit az eddig alkalmazott módszerek e csoportról megállapítani engednek.

Hogy a szóban forgó sejteknek s így közvetve a lateralis csoport elemeinek is valószinüleg vonatkozásuk van a hátulsó ereszték némely rostjaihoz, arról már föntebb szóltam.

A kifejlődött kutya gerinczvelejének vizsgálatára ugyanazo. kat deríthetjük $\mathrm{ki}$, mint az embernél. Az elmondottakhoz alig csatolhatnék valamit. Egyedúli különbség az, hogy az egész csoport aránylag gyengébb, s kivált a széli zona keskenyebb valamivel. Elhatárolódása itt is éles a Burdach-féle nyalábok felé, rostjainak finom volta és lazább szövete útján. A Rolando-féle állomány hátulsó, szegélyszerï részében, a "zona spongiosa posterior")-ban szintén megleljük a gyér idegfonatot, az ívjárású rostokat s a néhány idegsejtet. Magának az állománynak lateralis részén számos finom idegszál halad át, a melyek elöre tartva, az ez állomány elött lévő gazdag és sejtekkel megrakott ideghálózatban vesznek el. A viszonyok tehát csaknem egészen ugyanazok, mint az emberben.

A macska gerinczvelejében a 7. napon láttam legelöször néhány elszórt velös rostot a Lissauer-féle területen, de a Rolandoféle állományon átnyomuló rostokból és az ideghálózatból ez idötájban még mi sem látható. A 15. napon e részekben is megindúl a velösödés. Kifejlödött macska gerinczvelején, a lateralis csoport, az embernél észlelhető typustól, csak valamivel gyengébb volta által különbözik.

A lateralis esoport a tengeri malaczban már a születés idejében jórészt velös, de tökéletesen velösnek esak a 10. napon találtam. E csoport itt egyáltalán igen silány fejlödésú, külön esoport nevére semmikép se tarthat számot. A Rolando-féle állomány hátúl, két belsö harmadában még a Burdach-féle nyalábok szegélyszerủen megvékonyodott folytatásától boríttatik. Lateralis harmada úgyszólván a peripheriáig ér; rendkívül kevés, szétszórt, hosszában futó rost választja el töle. A széli zonának tehát, a mely az embernél aránylag oly erős, itt alig 
van nyoma, de a megfelelö elemek nem hiányzanak teljesen, csak másutt járnak. Az oldalsó nyalábok leghátulsó részében, a Rolando-féle állomány külsö vége s a peripheria között van ugyanis egy zug, a hol az erös gliasövények közti hézagokban durvább rostokon kívül számos finom rostú, tölük világosan megkülönböztethető nyaláb jár; e szögletnek, úgy látszik, vonatkozása van a lateralis esoporthoz.

A Rolando-féle állomány leghátulsó része szintén ideg nemü alkotású $\mathrm{E}$ szegélyszerü területen több ívjárású rost jelen meg, a melyek a hátulsó gyökerekböl válnak le, s részben az oldalsó nyalábok leghátulsó részébe bocsátkoznak, részben átvonúlnak a Rolando-féle állományon; van itt azonkívül 1-2 idegsejt s igen gyenge ideghálózat. Sokkal erösebb az az ideghálózat, a mely elöl, ez állomány homorúságában s kivált annak külsö recessusában van. E sürü recze leginkább hosszában összefonódó rostokból áll - hosszanti szeleteken erröl biztosan meggyőződhetünk - s hézagjaiban több apró idegsejtet tartalmaz. A Rolando-féle állomány külső felén számos finom rost lép át, a melyek részben direct a hátulsó gyökerekből válnak le, részben az oldalsó nyalábok hátulsó szögletéböl jönnek s elöl a hálózatos zỏnába merülnek.

A hátulsó ereszték néhány finomabb rostja, mint már elmondottam, szintén e hálózatból ered.

$\mathrm{Az}$ egérben még nagyobb reductióval találkozunk az oldalsó csoport tekintetében. A Rolando féle állomány két oldalsó harmada a gerinczvelö legtöbb pontján a peripheriáig ér ; esak elvétve észlelünk mögötte néhány rost-átszeletet. Ez állomány hátulsó széle mentén a legtöbb szeleten néhány finom, ívalakban járó rost látható, a melyek a hátulsó gyökerekböl az oldalsó nyalábok hátulsó zugába mennek, (ezek össze nem tévesztendők a középső csoport hasonló járású és fekvésü, de vastagabb "körülhajló rostjai»-val). E szögletben a fehér állomány belsö alkotása igen emlékeztet a Lissauer-féle zonáéra: erös alapállománynyal, összefonódó sövényekkel, bír, a melynek hézagjaiban finom rostú, szétszórt nyalábok futnak. Ezt a kis területet tarthatjuk tehát a Lissauer-féle zona gyenge analogonjának.

Nevezetes különbség itt még a tengeri malaczhoz képest az is, hogy azok a Rolando-féle állomány oldalsó részén átnyomúló 
finom idegrostok, a melyekkel az embernél s valamennyi állatnál találkoztunk, itt teljesen hiányoznak; ez állomány oldalsó $2 / 3$-a idegrostot nem tartalmaz, az egyöntetú sárga mezön egy fekete idegfonál sem emelkedik ki. Egy állat sem szolgáltatja annak meggyőzőbb tanúságát, mint az egér, hogy a tulajdonképeni formatio Rolandica - leszámítva leghátulsó részét idegnemủ alkotó részeket nem tartalmaz, hanem egyedül elszarusodott ektoderma-sejtekböl rakódik össze.

A Rolando-féle állomány homorúságát kitöltö hálózatnak is csak silány nyomai jelennek meg; csak néhány rost-ponttal, ferde töredékkel találkozunk e helyen. E hálózatban az említett zugból néhány rost bocsátkozik be.

A velösödés idejét illetöleg fölemlíthetem, hogy 18 napos egérben az oldalsó nyalábok hátulsó szöglete még jóval világosabb szinú e nyalábok többi részénél, a mi annak a következménye, hogy elemeinek csak egy része, csak a vastagabb idegrostok velősek még. A rosthálózatból se látható ez időtájban még semmi sem. Mind e részek esak a 25-ik nap körül mutatkoznak teljes velösségben.

\section{Összefoglalás.}

1. A finom rostú, későn velösödő lateralis csoport esak az emberben, meg a ragadozókban (kutya, macska) tesz számbajövő nyalábot, a rágesálókban (tengeri malacz, egér) alig találjuk nyomait.

2. Rostjai, leválva a hátulsó gyökerekröl, a Rolando-féle állomány s a gerinczvelö kerülete közt egy kis hosszában járó nyalábbá, Lissauer széli zonájává esoportosúlnak.

3. Rágcsálókban e zona ssaknem teljesen hiányzik, gyenge analogonja gyanánt az oldalsó nyalábok leghátulsó részében lévő kis szögletszerü területet ismerjük fel.

4. A Lissauer-féle zona alkotó részei utóbb ismét vízszintes irányba térnek át, s egyenesen átmennek a Rolando-féle állomány oldalsó részén.

5. Ez állomány homorúságában több apró s néhány nagyobb, többsarkú idegsejt van, a melyeknek szétágazódó nyújtványai súrú hálózattá kapcsolódnak egybe. A lateralis csoport 
A GERINCZVELÖI IDEGEK HÁTULSÓ GYÖKEREIRÖL.

45

elemei e hálózatba merúlnek s ennek útján valószínúleg a sejtekkel függnek össze. Az egéren e hálózat csak nyomaiban van meg.

6. A hátulsó ereszték számos oly rostot foglal magában, a melyek nem jönnek egyenesen a hátulsó gyökerekből, hanem e hálózatból, s ennek útján valószínủleg az említett sejtekböl erednek.

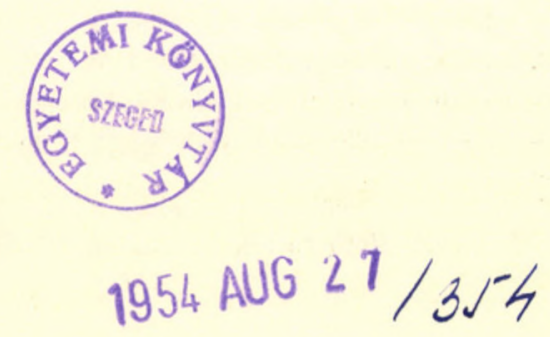




\section{AZ ÁBRÁK MAGYARÁZATA.}

Az ábrák valamennyien gyenge nagyítással (Reichert. sc. I., obj. 1.) vannak rajzolva, kivéve az j-iket, a mely közepes nagyítás mellett (Oc. I., obj. 2.) késziült. Weigert-féle festés.

1. Szelet, $28 \mathrm{~cm}$. hosszú magzat gerinczveleje ágyéki részéből.

2. $36 \mathrm{~cm}$. h. magzat gerinczveleje ágyéki részéből.

$3.36 \mathrm{~cm}$. h. magzat gerinczveleje háti részéből.

4. Kifejlődött tengeri malacz gerinczvelejének ágyéki szakaszából.

5. Újszïilött gyermek gerinczvelejéböl. Hátulsó szarv és Lissauerféle széli zona.

6. A hátulsó gyökerek gerinczvelöbeli járásának schemája. A pontozott részek az illetö rostok hosszában futó darabjait tüntetik elö. 

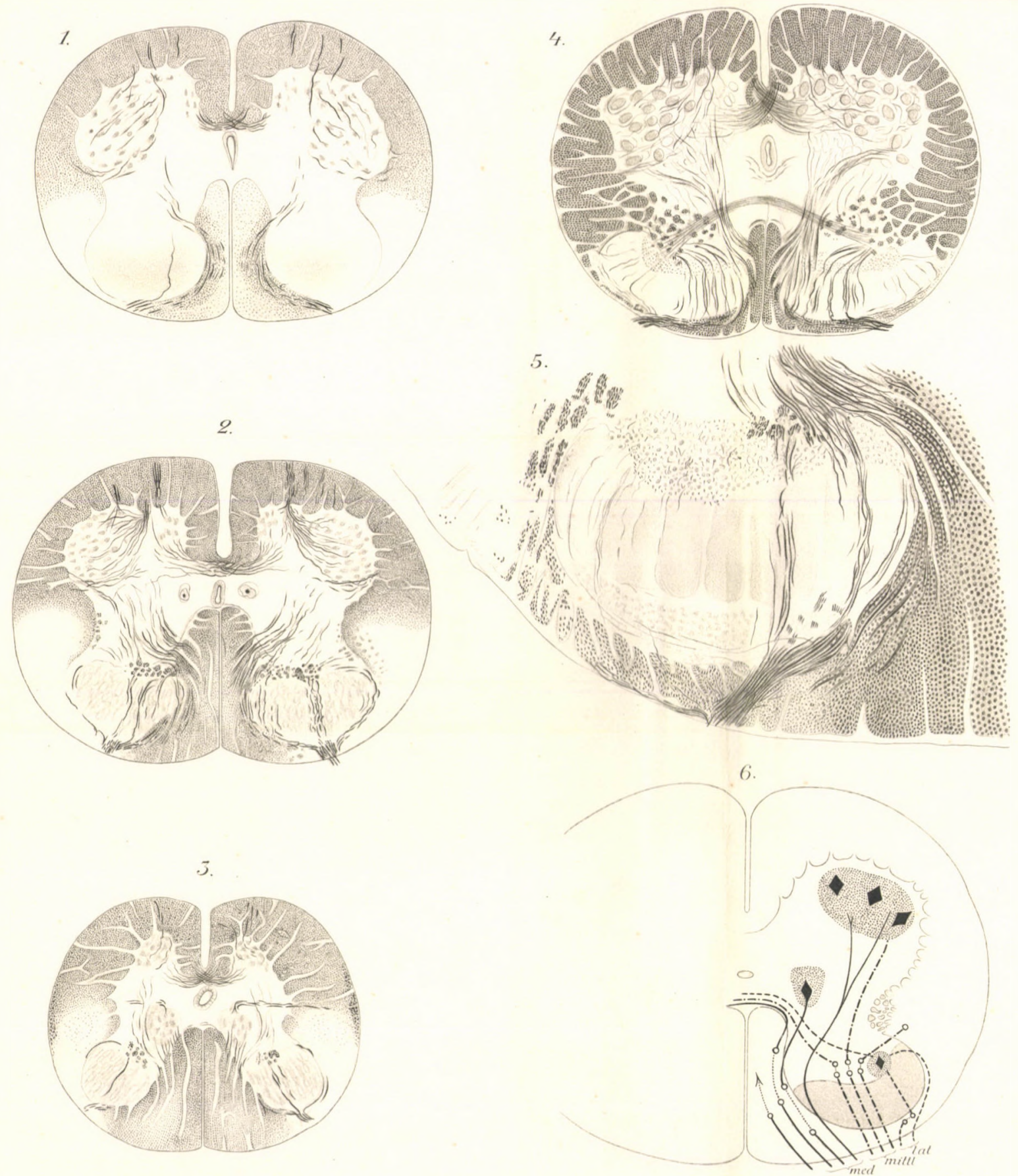

M. Tud. Ak. Evitek. a Természettud. Köréböl. 1889. XIX. K. 6.sz. 





\section{Tizenkettedik kötet 1882 .}

I. Baryt és Cerusit Felekesröl Borsodmegyében. (Négy könyomatú táblával.) Schmidt Sándortól. - II. Kristálytani és optikai vizsgálatok az aranyhegyi Amphibolon. (Egy képtáblával.) Franzenau Ágostontól. - III. Értekezések a myo-mechanika köréből. Jendrássik Jenötől. - IV. Helyreigazitó észrevételek Thanhoffer Lajos urnak aAdatok a harántesiku izmok szerkezete és idegvégződéséhez" czimii székfoglaló értekezéséhez. Jendrâssił Jenötöl. V. A Vampyrella fejlölése és rendszertani állása. (Két táblával.) Klein Gyulától. - VI. Az Aquilegiák rendszere és földrajzi elterjedése. (Systema et area Aquilegiarum geographica.) Dr. Borbás Vinczétöl. - VII. A szénkönenyek égése chlórgázban. P. Kiss Károlytól. - VIII. Adatok a növények, különösen az Euphorbiceák tejnedvének ismeretéhez. (Két táblával.) Dietz Sándortól. IX. Helyreigazitó észrevételek Jenđrássik Jenő ur “Helyreigazitó» etc. "Észrevételeire». Thanhoffer Lajostôl. - X. Adatok a Cestodák ismeretéhez, a Solenophorus Megalocephaluson megejtett vizsgálatok alapján. (Tizenhét ábrával.) A heidelbergi egyetem állattani intézetéböl. Dr. Roboz Zoltántól.

\section{Tizenharmadik kötet 1883 .}

I. A Clavulina Szabói-rétegek, az Euganeák és a tengeri Alpok terïletén, - és a krétakoru "Scaglia" az Euganeákban. (Négy táblával.) Hantken Miksától. - II. Az Eremocoris-fajok magánrajza. (Két táblával.) Horvâth Gézától. - III. A modern zoologia szempontjai s ezéljai. (Székf.) Kriesch Jänostôl. - IV. A rovarok dimorphismusáról. (Egy tábla rajzzal.) (Székf.) Horváth Gézától. - V. A parádi timsós, Ilonavölgyi timsós és a Clarisse-forrás vizének vegyelemzése. Dr. Lengyel Bélától. - VI. A Sibrai (Sivabrada) fürdő ásványvizének vegyelemzése. Scherfel V. Auréltól. - VII. Dolgozatok a k. m. tud. egyetem élettani intézetéböl. (III. füz.) Közli Jendrássik Jenö. 1. A folyadékok áramlása hajszálesövekben. (Öt ábrával.) 2. Adatok a fehérnyeoldatok átszivárgásához. Dr. Regéczi Nagy Imrétöl. - VIII. Uj vagy kevésbbé ismert hasgombák. Gasteromycetes novi vel minus cogniti. (Öt táblával.) Kalchbrenner Kärolytól. - IX. Az állatország renđ̧szeres osztályozása, különös tekintettel az újabb állattani rendszerekre. (Egy rajztáblával.) (Székf.) Dr. Margó Tivadartól. - X. A czemétei ásványviz vegytani elemzése. Scherfel V. Auréltól. - XI. Hymenoptera nova Europaea et exotica. Európai és másföldi uj Hártyaröpizek. Mocsáry Sändortól. - XII. Hunyadmegye ásványvizei. Dr. Hankó Vilmostól. - XIII. Vizsgálatok a löesei m. k. föreáltanoda vegytani intézetéből. Dr. Steiner Antaltól. - XIV. A petroleum lobbanási pontja meghatározásának egy uj módszere. Liebermann Leótól. - XV. Adatok a Cilioflagelláták ismeretéhez. (Véglénytani tanulmány. Egy rajzlappal. Dr. Daday Jenötöl.

\section{Tizennegyedik kötet. 1884.}

I. Egy tömegesen tenyészö légyfaj az Alsó-Duna mellékéröl. (Thalassomia congregata.) (Három tábla rajzzal.) Dr. Tömösváry Ödöntöl. II. A lakásviszonyok befolyása a cholera és typhus elterjedésére. $\mathrm{Dr}$. Fodor Józseftöl. - III. A esigolyaközötti dúezok és ideggyökerek fejlödéséról. (Két tábla rajzzal.) $D r$. Ónodi A. D.-töl. - IV. A keleti Kárpátok geológiai viszonyai. (Két szelvénynyel.) Dr. Primics Györgytöl. - V. A külsö hömérsék befolyása a csecsemök szervezetére. Dr. Eröss Gyulától. - VI. Uj adatok a Buda-nagykovácsii hegység és az esztergomi vidék föld- és öslénytani isme. retéhez. Dr. Hantken Miksâtól. - VII. A folyami rák zöld mirigyének bonez-, szövet- és élettana. (Két táblával.) Szigethy Kurolytól. - VIII. Tanulmány a Najadeák szövettanából. (Négy táblával.) Ifj. Apáthy Istvảntól. - IX. Az associált szemmozgások idegmechanismusáról. III. közlemény. (Egy fametszettel, hat táblázattal s egy szines körajzzal.) Dr. Högyes Endrétöl. (Székf.) 
I. Asványelemzési közlemények. Loczka Jozseftöl. - II. Gróf Széchenyi Béla közép-ázsiai expeditiójának növénytani eredményeiröl. (Székf.) Kanitz Ágosttól. - III. Selmecz geológiai viszonyainak előzetes ismertetése. Dr. Szabó Józseftöl. - IV. A tátrafüredi Hygiea-forrás vegyelemzése. Scherfel V. Auréltôl. - V. A koronahegyi fürdö (Smerdzonka) kénesvizének vegyelemzése. Scherfel V. Auréltól. - VI. A Beregmegyében levỏ bilásoviczi Irmaforrás ásványvizének vegyelemzése. Nendtvich Károlytöt. - VII. A szliácsi források chemiai elemzése. (Székfoglaló.) Than Károlytól. - VIII. A bártfai fürdő ásványvizeinek chemiai elemzése. Dr. Ossikovszky Józseftöl. - IX. A vámfalusi és túrvékonyi ásványvizek vegyelemzése. Nendtvich Károlytól. X. Bacteriumok az élö állatok vérében. Fodor Józseftöl. - XI. Magyarország ásványvizei. Nendtvich Kârolytól. - XII. Vizsgálatok újszülött gyermekek rendes hőmérséki viszonyaira vonatkozólag. Eröss Gyulától. - XIII. A szemlencse fejlödésének első mozzanatairól a gerinczeseknél. Korányi Sândortól. XIV. Dolgozatok a k. m. tud. egyetem élettani intézetéböl. (IV. füz.) Közli Jendrássik Jenő. 1. Észrevételek az osmosis elméletéhez. Nagy Imrétől. 2. Az izommagvakról. Rothman Ármintól. - XV. Dolgozatok a k. m. tud. egyetem élettani intézetéből. (V. füz.) Közli Jendrássik Jenő. 1. A sima izomzat gyarapodása és pótlódása. Ifj. Apáthy Istvántól. 2. Adatok a gerinczagyi dúczok ismeretéhez, a békán tett vizsgálatok alapján. Lenhossél Mihálytól. - XVI. Progén koponyák. Dr. Lenhossék Józseftöl. - XVII. Magyarország erdőségei. Bedö Alberttöl. - XVIII. A palaearktikus övben élö terrikoláknak revisiója és elterjedése. Örley Lászlótól. - XIX. Az együttérző idegrendszer fejlödése. Ónodi A. D.-töl.

\section{Tizenhatodik kötet. 1886.}

I. Adatok a pókok boncz- és fejlödéstanához, különös tekintettel a végtagokra. Lendl Adolftól. - II. Közlemények az állatorvosi élettani intézetböl. II. Eszközök és vizsgálatok. Thanhoffor Lajostól. - III. Ujabb kisérletek erekbe feeskendezett bacteriumokkal. Fodor Józseftöl. - IV. Adatok a Gregarinák ismeretéhez. Rob@z Zoltântól. - V. Ritkább boncrtani rendellenességek. Egy táblával. Lenhossék Mihálytól. - VI. A magyarországi Obsidiánok, különös tekintettel geologiai viszonyaikra. Szádeczky Gyulâtól. - VII. Új adatok Erdély denevér-faunájának ismeretéhez. Dr. Daday Jenötöl.

\section{Tizenhetedik kötet. 1887.}

I. Göd környéke forrásainak geologiai s hidrografiai viszonyai. Egy térkép és 5 fametszettel. Szabó Józseftöl. - II. A Sparganium T. és Typha T. virág és termés fejlödése. 8 tábla rajzzal. Dietz Sándortól. - III. A brassói hegység földtani szervezetéröl és talajviz viszonyairól. Koch Antaltól. IV. A vérnek baktérium ölö képességéröl. Fodor Józseftöl. - V. Dolgozatok a k. m. tud. egyetem élettani intézetéböl. (VI. füzet) Regéczy Nagy Imrétöl. VI. A növények talajálló irányának okairól. Dietz Sándortól.

\section{Tizennyolozadik kötet. 1888.}

I. A környezet hatása a hömérökre. Hegyfoky Kabostól. - II. A pókok, különösen a kerekhálós pókok természetes osztályozásának kisérlete. Lendl Adolftól. - III. A XIX. század physikai kutatásának mozgató eszméiről. Heller Ágosttól. - IV. Kórodai adatok a fertőzö betegségek ismeretéhez. Korányi Frigyestöl. - V. A veszettség gyógyitásáról. Dr. Högyes Endre 1. tagtól. VI. Kisérleti adatok a Porret-féle izomtünemény jelentőségének kérdéséhez. Regéczy Nagy Imrétöl.

\section{Tizenkilenezedik kötet. 1889.}

I. Az erdélyi havasok az Olt szorostól a Vaskapuig. Inkey Bélától. II. A kiskartali csillagvizsgálóról. Kövestigeti Radótól. - III. A pióczafélék külső alaktanáról. 27 ábrával. Apáthy Istvántól. - IV. A modern növénytan törekvései. Klein Gyulâtól. 